\title{
La riconnessione delle città costiere. La rete dei fari italiani
}

\author{
Sonia Mollica \\ Andrea Marraffa
}

Abstract

II paper ha l'obiettivo di esplicitare una metodologia di studio per la valorizzazione del patrimonio culturale, in linea con il piano strategico regionale di sviluppo turistico 2019/2023 della regione Sicilia, sperimentata durante lo sviluppo di una ricerca, a partire dall'analisi e dallo studio della rete dei fari presenti nell'Album dei fari d'Italia, risalente al periodo post-unitario. Per una efficace narrazione e visualizzazione dei luoghi, si sono messe in atto, secondo un piano teorico, nuove tecnologie per la fruizione del Cultural Heritage, quali ad esempio, il video mapping, per la creazione di un nuovo Gran Tour dei luoghi. II progetto vuole favorire e potenziare l'offerta turistica siciliana, in prospettiva di un programma organico più ampio che preveda uno sviluppo territoriale più inclusivo [I], sostenibile e culturalmente accessibile. Si vuole, dunque, considerare la narrazione di luoghi unici e complessi, connessi tra loro, capaci di mettere in atto reciproche contaminazioni e, al netto della creazione di una fitta rete, d'instaurare un empowerment del proprio valore intrinseco che, a questo punto, non sarà più pari alla somma delle singole identità costiere.

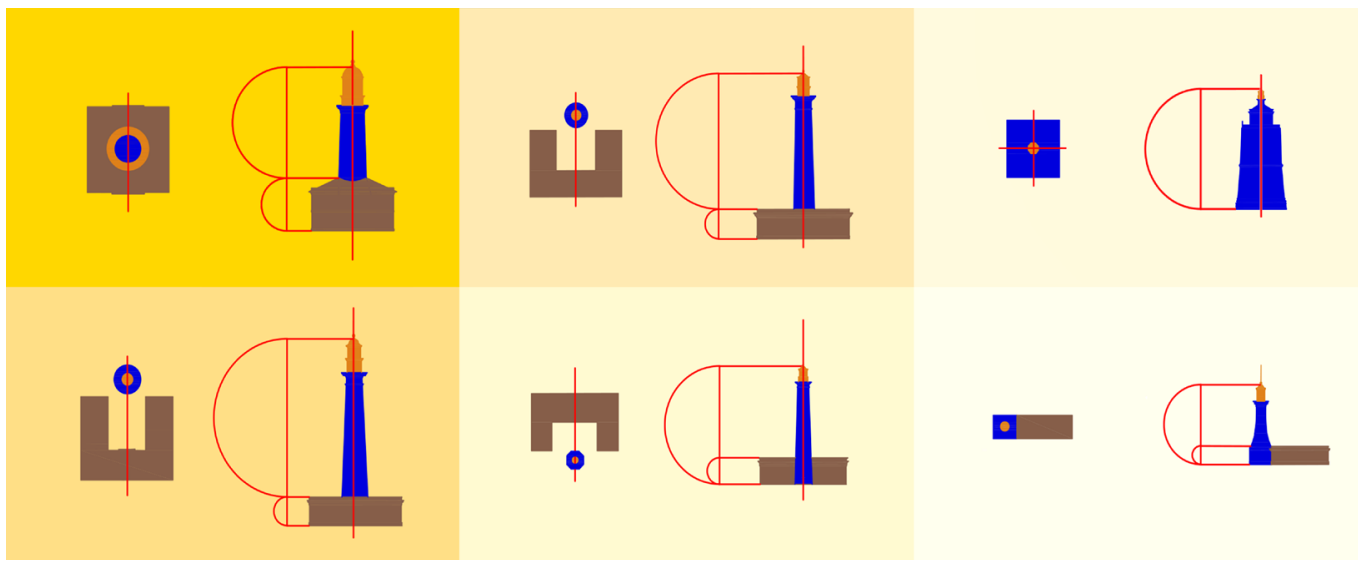




\section{Introduzione. Storia dei fari italiani: dal mito alla rovina}

La figura del faro ha da sempre incuriosito l'immaginario collettivo, la nascita di queste architetture risale ad epoche lontanissime e la loro trasformazione va di pari passo con il progredire delle tecnologie di navigazione. Già Omero nel XIX libro dell'lliade paragona il luccichio dello scudo di Achille ad uno di quei fuochi che si ergono dalle alture e che rendono sicura la via ai naviganti ma il concetto di 'faro' nasce solo nel 300 a.C. con il Colosso di Rodi e con il faro di Alessandria.

L'impero romano vede la nascita delle prime torri in pietra con un fuoco acceso alla sommità. A questa epoca segue un periodo buio per la costruzione dei fari, terminato solo durante l'età moderna, periodo durante il quale le torri-faro riacquistano una nuova forza di avvistamento.

Con la rivoluzione industriale, poi, i sistemi di segnalazione si modificano grazie alle innovazioni tecnologiche di quegli anni, le torri si trasformano in fari, formati da corpi simmetrici, da torrette e da lanterne, popolando i luoghi più suggestivi delle coste marine con segnali luminosi propagati da lenti 'Fresnel', azionati dai faristi che li abitavano.

Oggi, l'awvento dei sistemi automatizzati di accensione della lanterna segna un'ulteriore evoluzione di questi manufatti che, pur mantenedo l'alto valore simbolico e identitario, non vedono più, in molti casi, il loro uso di abitazione, causando la repentina e inesorabile trasformazione degli edifici in relitti della storia, lacerti di memoria ormai passata.

Fig. I. Studio e analisi su cartografia di base presente nell'Album dei Fari d'Italia.
Fig. 2. Modelli tridimensionali su base dei progetti presenti nell'Album dei Fari d'Italia. Srotolamento della costa italiana.

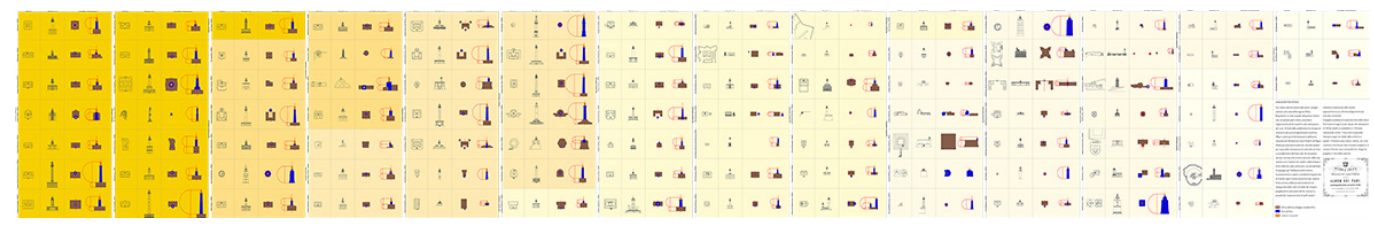

\section{L'Album dei fari d'Italia 3.0 metodologia della ricerca: le nuove connessioni digitali}

Il tema dell'accessibilità [2] al patrimonio culturale e della valorizzazione dell'arte e del patrimonio artistico, appaiono come colonne portanti di quelle che sono le principali programmazioni tra cui: il piano strategico regionale di sviluppo turistico 2019/2023 della regione Sicilia, l'Agenda 2030 [3] e i principali settori ERC. Sulla base di esse si vuole intraprendere e sviscerare una ricerca sviluppata presso l'Università Mediterranea di Reggio Calabria, dal titolo II faro di San Vito Lo Capo: dalla rete dei fari d'Italia al rilievo del manufatto architettonico, per un Grand Tour delle coste siciliane, basata sul concetto di rete e sullo studio del manufatto costiero.

Al fine di soddisfare una domanda sempre più crescente e articolata di percorsi turistici-culturali, l'organizzazione a rete si dimostra come una strada efficace e di successo. Lo studio verso la creazione di una metodologia replicabile di tipo reticolare individua come prima fase di ricerca la ri-lettura dei manufatti costieri, elencati e schedati ne l'Album dei fari d'Italia, la prima raccolta organica di queste architetture, realizzata all'indomani dell'Unità del Regno d'Italia. L'Album dei Fari rappresenta un vasto progetto del governo italiano che provvide alla redazione di un programma finalizzato alla realizzazione di nuovi fari e al miglioramento di quelli esistenti la cui formalizzazione costituisce l'ufficializzazione dell'iniziativa intrapresa dal Ministero dei Lavori Pubblici del Regno d'Italia per potenziare la serie dei manufatti esistenti per mezzo della realizzazione di molte altre torri-faro a completamento dell'intera rete.

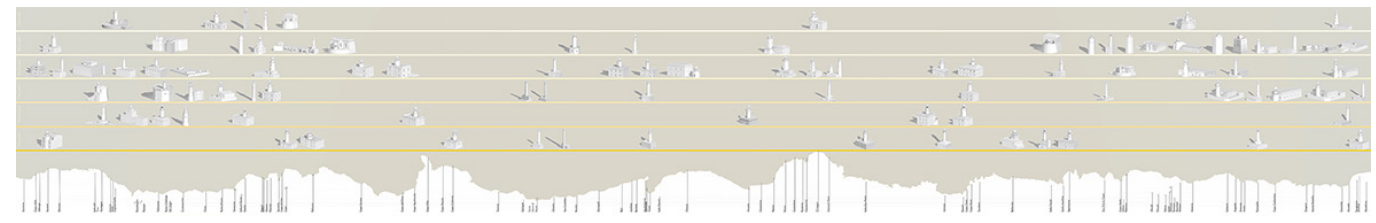




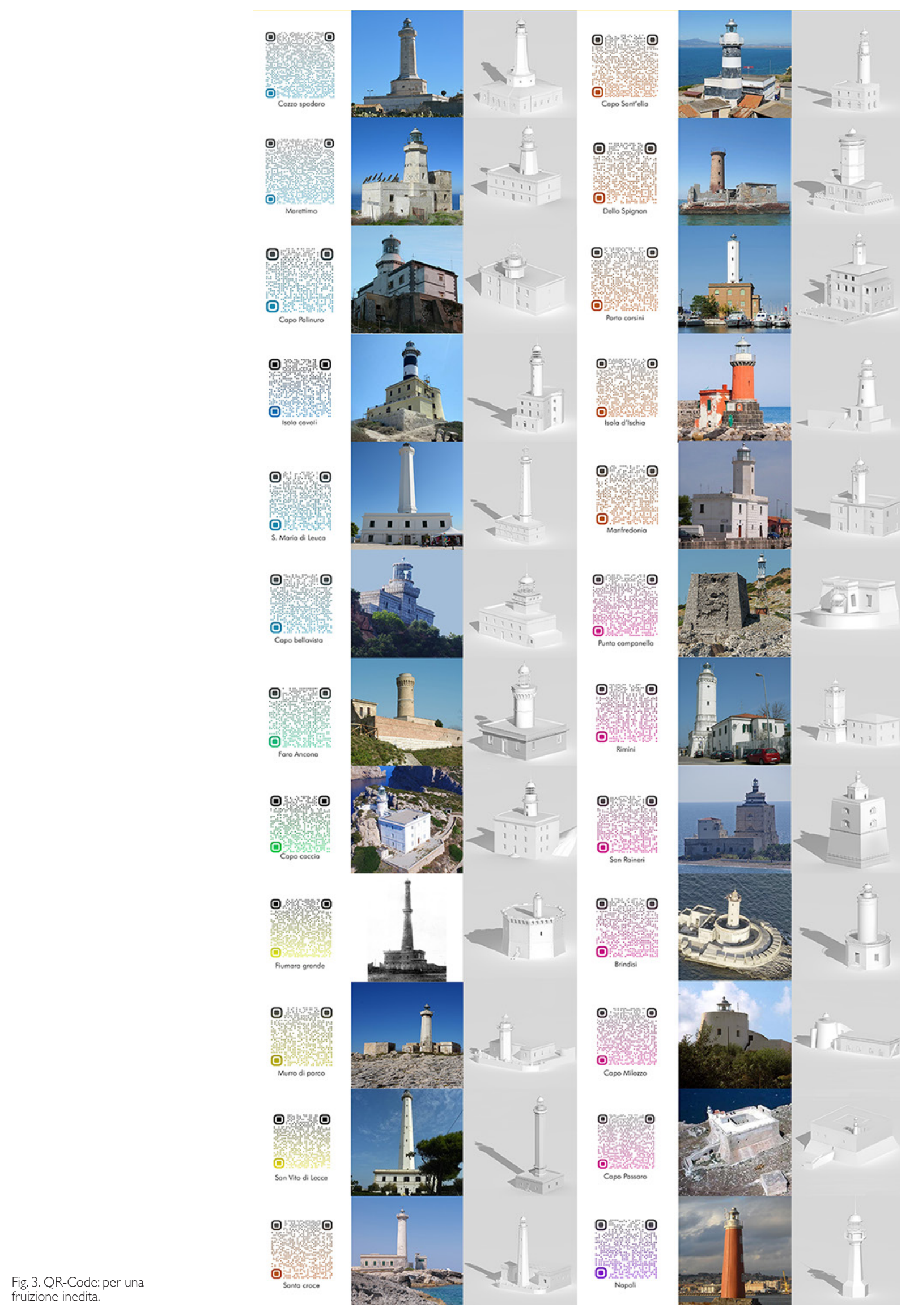


II governo, però, non fu in grado di portare avanti un progetto costruttivo di tale portata, infatti, sono nettamente visibili quelle che sono le modifiche formali tra i disegni progettuali dell'epoca e il manufatto architettonico odierno.

Nell'intento di attuare quella che si propone come una metodologia di ricerca basata sulla rilettura dei punti identitari costieri, al fine di creare percorsi co

noscitivi, si è reso necessario elaborare come prima fase di ricerca il ridisegno di quelle che sono le geometrie dei novantaquattro fari posti in essere nella documentazione ufficiale, in modo da estrapolarne moduli e geometrie, instaurando una più semplice comparazione formale tra le architetture costiere (fig. I).

Il ridisegno è stato propedeutico per l'elaborazione di modelli tridimensionali formulati sulla base della documentazione presente nell'Album dei fari e su svariati riferimenti fotografici, grazie ai quali si è raggiunto un livello di dettaglio architettonico capace di trasmettere quelli che sono i rapporti volumetrici e spaziali dell'architettura costiera del periodo post unitario secondo una visione inedita. La seconda fase, dunque, mette in campo delle argomentazioni esclusive che trovano la propria rappresentazione esplicativa nella lunga costa italiana dispiegata secondo il metodo dello 'srotolamento' [Nucifora 2006]. Quest'ultimo non è altro che un espediente grafico che utilizza dei punti di rotazione coincidenti con i fari, che, al netto del compimento della rotazione, giaceranno su una linea verticale. Per comprendere al meglio il sistema rappresentativo della tavola si è resa necessaria una duplice lettura, infatti, l'impaginato è, inoltre, suddiviso secondo linee orizzontali, linee con differenti gradazioni di colore, al fine d'individuare con un singolo colpo d'occhio gli ordini dei fari, stabiliti in base alla portata della luce del fanale (fig. 2).

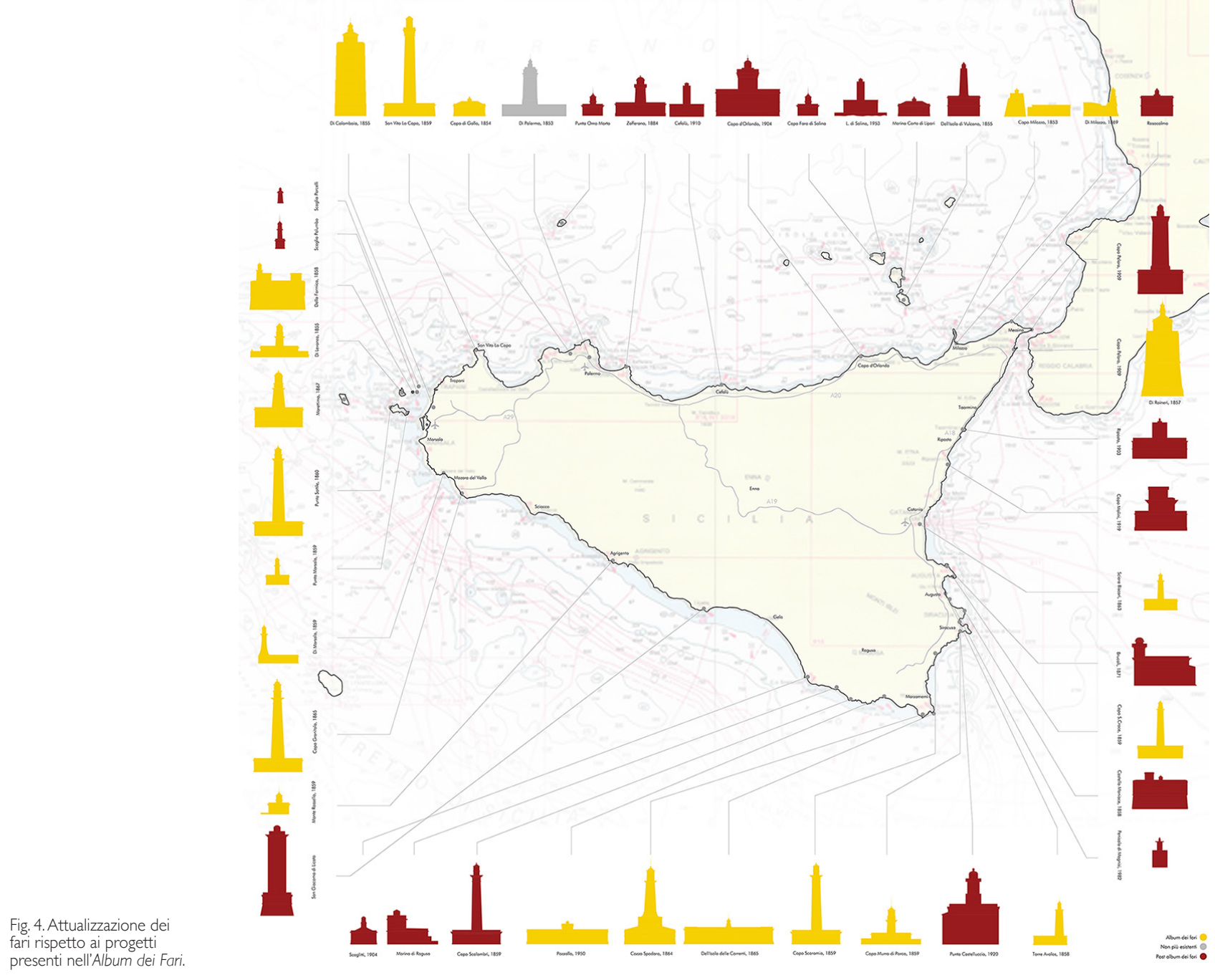


Al fine di rendere fruibili nella loro interezza i modelli tridimensionali, ad ognuno di esso, sono associati dei QR-code (fig. 3), attraverso cui è possibile essere indirizzati verso una piattaforma informatica online ove poter leggere in tre dimensioni i modelli digitali. Qui, i modelli si prestano a una lettura totale: è possibile girare intorno all'architettura, entrare al suo interno e scegliere diverse modalità di visualizzazione.

II risultato della digitalizzazione e della modellazione tridimensionale di tutti i novantaquattro manufatti costieri costituisce il presupposto su cui si fonda la metodologia di studio qui delineata, per un progetto di messa in rete del patrimonio costiero attraverso cui sviluppare dei percorsi tematici di ricucitura e valorizzazione del territorio.

La metodologia, a questo punto, si traduce in quella che è la terza fase, determinata dalla 'ricognizione' dello stato di fatto dei manufatti costieri rispetto ai progetti delineati nell'Album dei Fari. Tale analisi ha messo in evidenza che circa la metà dei fari documentati ha subito radicali trasformazioni rispetto al progetto prefigurato durante I'Unità d'Italia e, soprattutto, che altrettanti fari siano stati progettati e realizzati in un periodo successivo (fig. 4). Ciò denota il segno di un paesaggio [4] in continua trasformazione e una necessaria presa di coscienza della fragilità di tali manufatti poco rispettati e poco considerati per la loro valenza storica, paesaggistica e architettonica.

Attuata la ricognizione di tutti gli odierni manufatti costieri, in questa proposta esclusivamente siciliani, e delle loro peculiarità spaziali e materiali, si è cercato d'incrementare i flussi turistici verso questi territori evocativi e di potenziarne il riconoscimento del loro valore identitario e culturale. Si sono, dunque, ipotizzati dei percorsi tematici atti a rendere più




esplicite le connessioni tra i punti cospicui del territorio costiero; percorsi differenziati che possano adattarsi a differenti tipologie di fruitori turistici: turismo sportivo - riserve naturali e vulcani (fig. 5), turismo d'arte - barocco (fig.6), turismo stagionale - spiagge (fig. 7), turismo enogastronomico (fig. 8). Questi rappresentano soltanto alcune delle possibilità attraverso cui le connessioni tra le parti del territorio si dispiegano e mediante i quali è possibile creare un pretesto che trovi come fine ultimo la valorizzazione e lo sviluppo del valore intrinseco del patrimonio comune.

Nella loro raffigurazione, i percorsi espletati risultano affiancati da dei QR-code attraverso cui essere reindirizzati verso un itinerario georeferenziato, facile da fruire anche ai meno avvezzi alla tecnologia. I percorsi sono stati scelti in modo da rendere possibile un turismo stabile, dunque non stagionale, come spesso accade nei territori del meridione, e di renderli appetibili a tutte le fasce di età e d'interesse. Per tale ragione, è inoltre possibile intersecare i diversi percorsi-rete, offrendo un livello di fruizione sempre più personalizzato e personalizzabile.

All'interno della strategia tematica adottata, i fari si rendono teatro di diverse tipologie di fruizione, sempre differenti a secondo dei percorsi; qui trova spazio la conclusione di questo viaggio nelle identità costiere siciliane, nel loro nuovo riutilizzo economico e sociale. Infatti, il manufatto costiero s'inserisce delicatamente in una rete turistica, avvalendosi dei sistemi propri dell'entertainment digitale: il video mapping; o ancora, si riscoprono quelli che sono i valori sociali e culturali tramandati da mestieri antichi, il trascorrere una notte in un faro insieme al suo guardiano rappresenta sicuramente un'esperienza unica ancora totalmente inesplorata in Italia. Questi sono i presupposti di un'idea turistica, seppur in stato embrionale, attraverso cui trarre slancio verso la riscoperta di nuove letture del territorio.

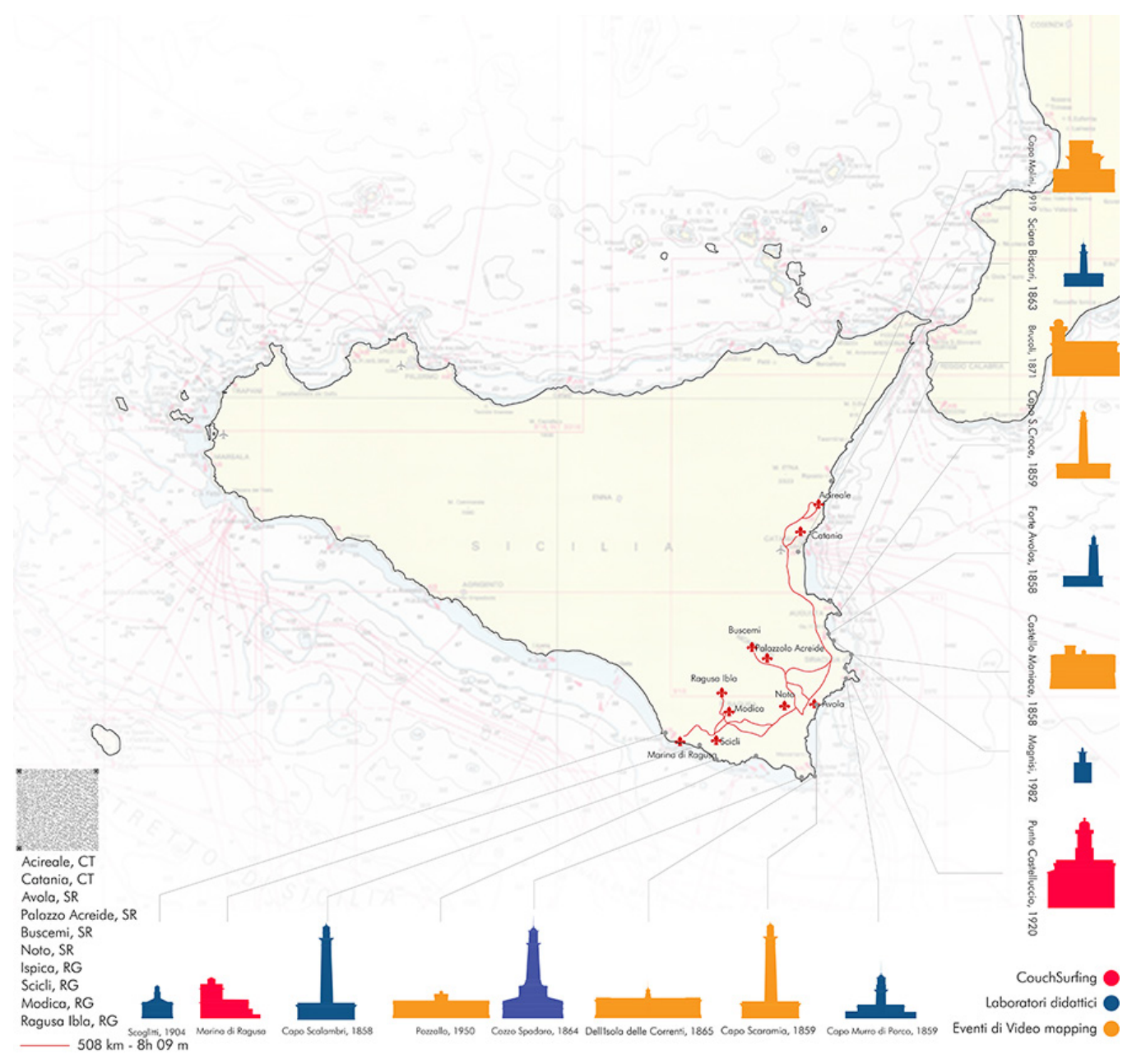




\section{Antiche identità dei luoghi, nuove narrazioni, inedite ri-connessioni}

Lo studio sui manufatti costieri, e in particolare sui fari, porta in sé una riflessione sul grande senso evocativo che questi esercitano sulla memoria di ciascuno di noi. Seguire un percorso vuol dire, in un certo senso, esplorare quella che è l'identità di un luogo, ipotizzarne la metamorfosi, capirne le continue modifiche e interrogarsi sul motivo che le hanno causate. In accordo con questa idea, al fine di dare una più corretta destinazione d'uso all'interno di questi percorsi-rete, si è voluto prendere in considerazione una specifica identità costiera siciliana, il faro situato a San Vito Lo Capo, grazie a cui, attraverso l'esecuzione di un'attenta campagna di rilievo integrato, è stato possibile studiarne le diverse modifiche storiche e spaziali.

L'analisi dello stato di fatto dell'insediamento architettonico, svolta sulla base di una campagna di rilievo eseguita con sistema fotogrammetrico sia aereo che terrestre (figg. 9- I I), ha restituito una mappa del luogo aggiornata e attendibile sulla potenzialità identitaria e ricettiva del faro. È su questi punti cardine che si fonda il criterio di selezione delle destinazioni d'uso dei fari nei percorsi tematici. II faro di San Vito lo Capo s'inserisce in questa rete come faro d'impetuosa importanza culturale e storica, per tale motivo, anche grazie alla sua grande offerta in termini di spazi architettonici, rende possibile la commistione di diverse fruizioni nello sviluppo di tutti i percorsi della Sicilia occidentale. L'aspetto ludico,

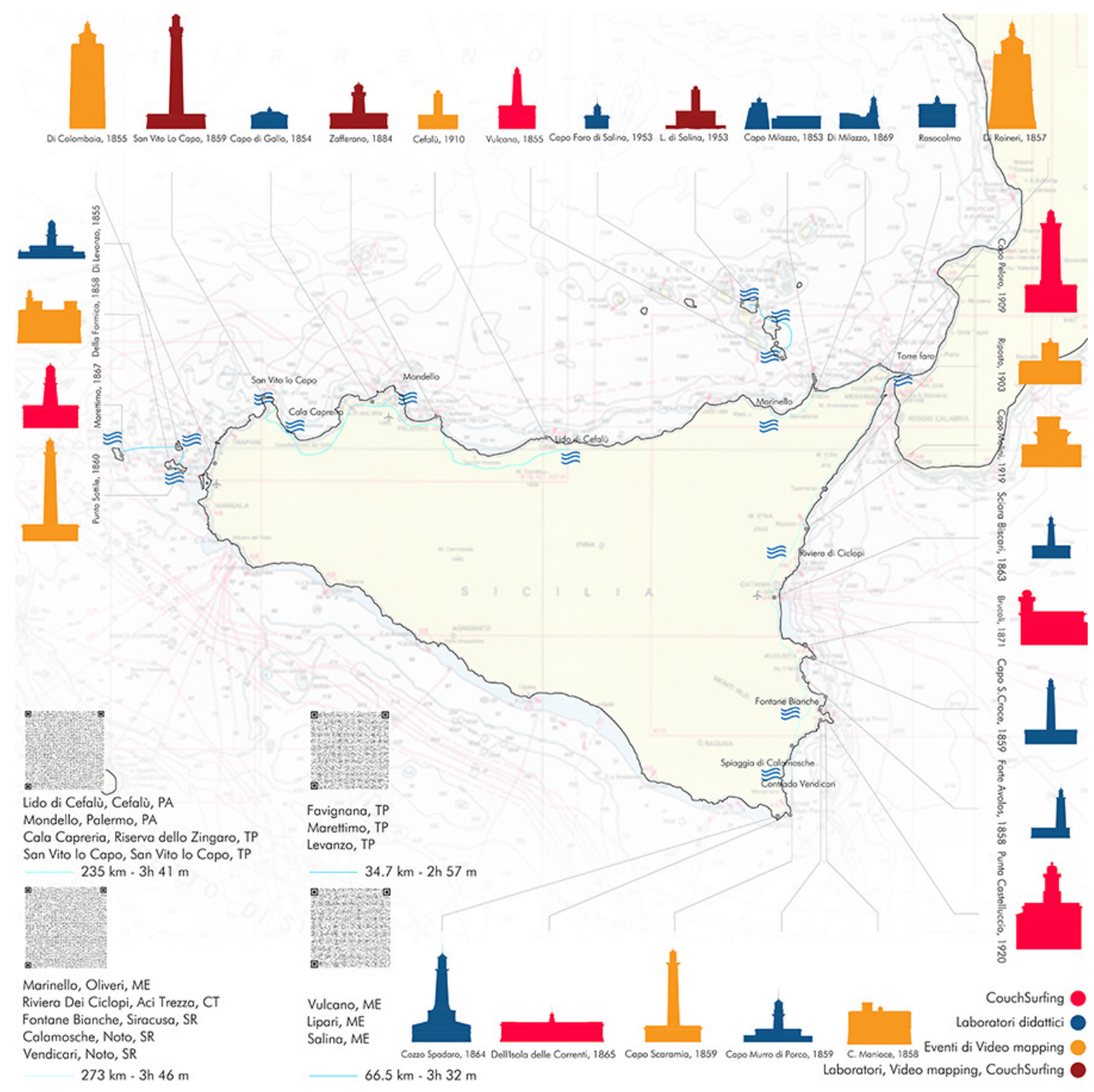


che lo vede come grande protagonista, merito della lanterna che svetta nel cielo con i suoi quarantadue metri di altezza, s'intreccia con quella che è l'affascinante routine del faro stesso, lo stare a contatto a tu per tu con il custode di leggende e miti.

Infatti, ogni identità costiera accoglie a sé storie antiche, il fascino di una realtà ignota. La riconnessione dei miti corrisponde alla riconnessione dei luoghi, alla realizzazione di una fitta trama che lega la storia al paesaggio, fondato su quella che è la visibilità, la temporalità, l'accessibilità e la narrazione [Venturi Ferriolo 2009]. Forte è il legame che unisce, dunque, il mito, la storia, la narrazione e il paesaggio. Si apre un gioco continuo tra evento e mutazione, narrazione e racconto. II susseguirsi degli avvenimenti crea scenari sempre nuovi da codificare [5], in cui la loro percezione si palesa sempre come organizzazione di dati percettivi, e non solo, è quello che secondo Morin con il suo homme imaginaire [6], alimenta le dualità, potenzia le connessioni, stimola l'unione tra reale e immaginario.

Sostanzialmente, si pone in evidenza il confronto tra 'storia' e 'memoria', un campo dove le tecnologie digitali e le ICT (Information and Communications Technology) possono giocare un ruolo fondamentale.

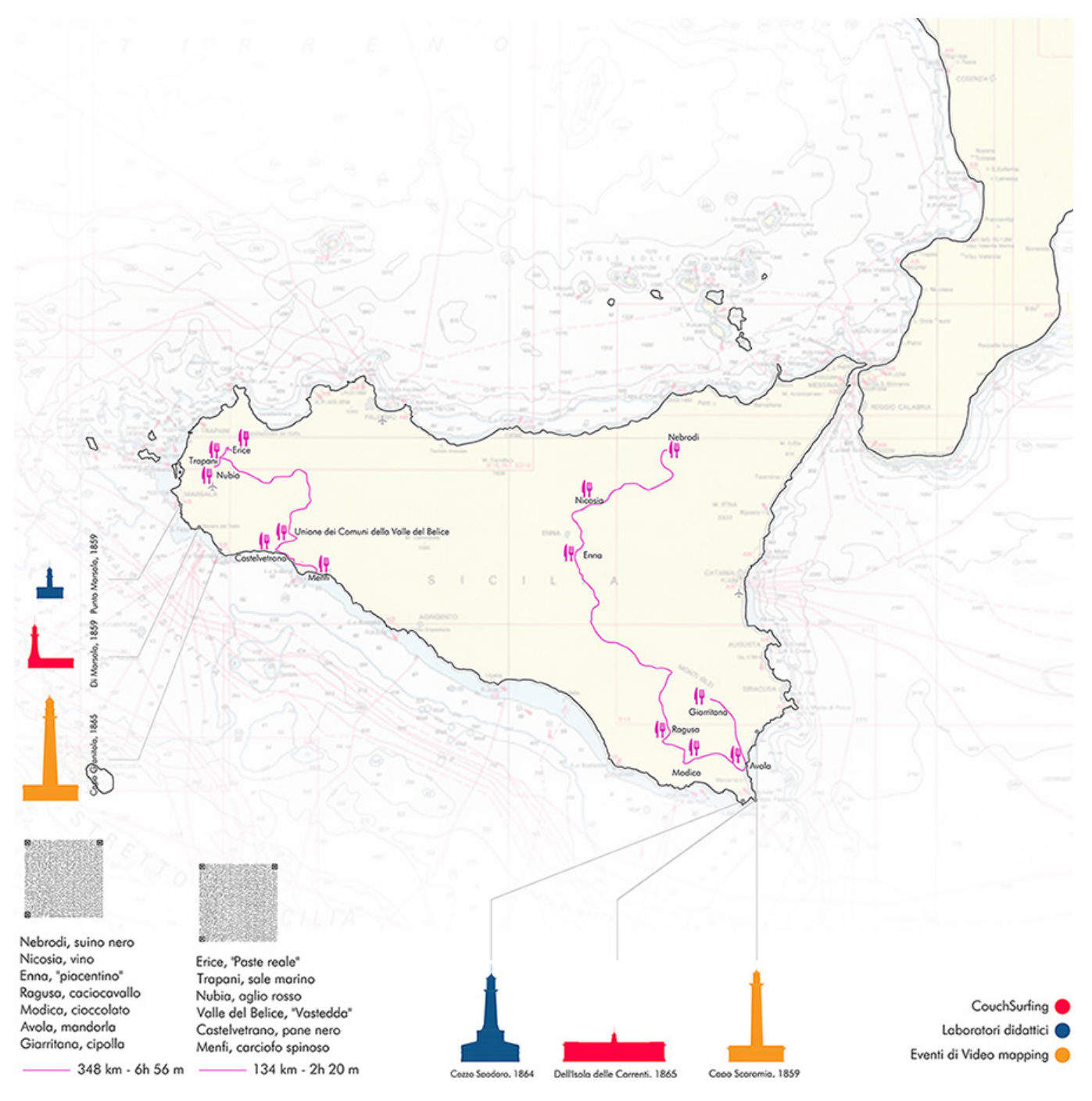




\section{II potenziale delle tecniche ICT per la riconnessione dei luoghi: le nuove strategie per l'inclusione culturale}

Negli ultimi anni, l'ambito culturale ha assunto dinamiche sempre più turbolente, soggetto spesso a repentine trasformazioni. Le istituzioni culturali, al fine di superare il gap esistente tra la fruizione e l'offerta proposta, e al fine di creare visioni sempre nuove e immaginifiche, si possono servire delle ICT [7], al fine di migliorare l'accessibilità, la comunicazione e la comprensione.

Sono molte le azioni adottabili per la valorizzazione e per la promozione del patrimonio comune, che pongono le loro basi su un'offerta territoriale sempre più articolata e integrata su diversi livelli e contesti di esperienza, attraverso cui si rende necessaria la messa in rete, il collegamento e il potenziamento delle altre risorse territoriali.

La rete qui proposta, infatti, individua il suo completamento progettuale, nonché la sua commistione tra l'universo tangibile e intangibile, in quella che vuole essere la tecnica più immersiva e adatta a fruizioni multisensoriali e multilivello: il video mapping. La realtà aumentata, a differenza della realtà virtuale, dona all'osservatore informazioni aggiuntive rispetto a quello che l'occhio umano riesce a percepire, e rende possibile l'integrazione tra la realtà fisica materiale e le nuove conoscenze culturali e storiche di tipo immateriale. Attraverso questa tecnica, infatti, è possibile raccontare e dipingere di luce i cambiamenti spaziali di un luogo, illustrare storie immaginifiche di reti e percorsi, narrare miti e leggende di cui sono pregne queste architetture.

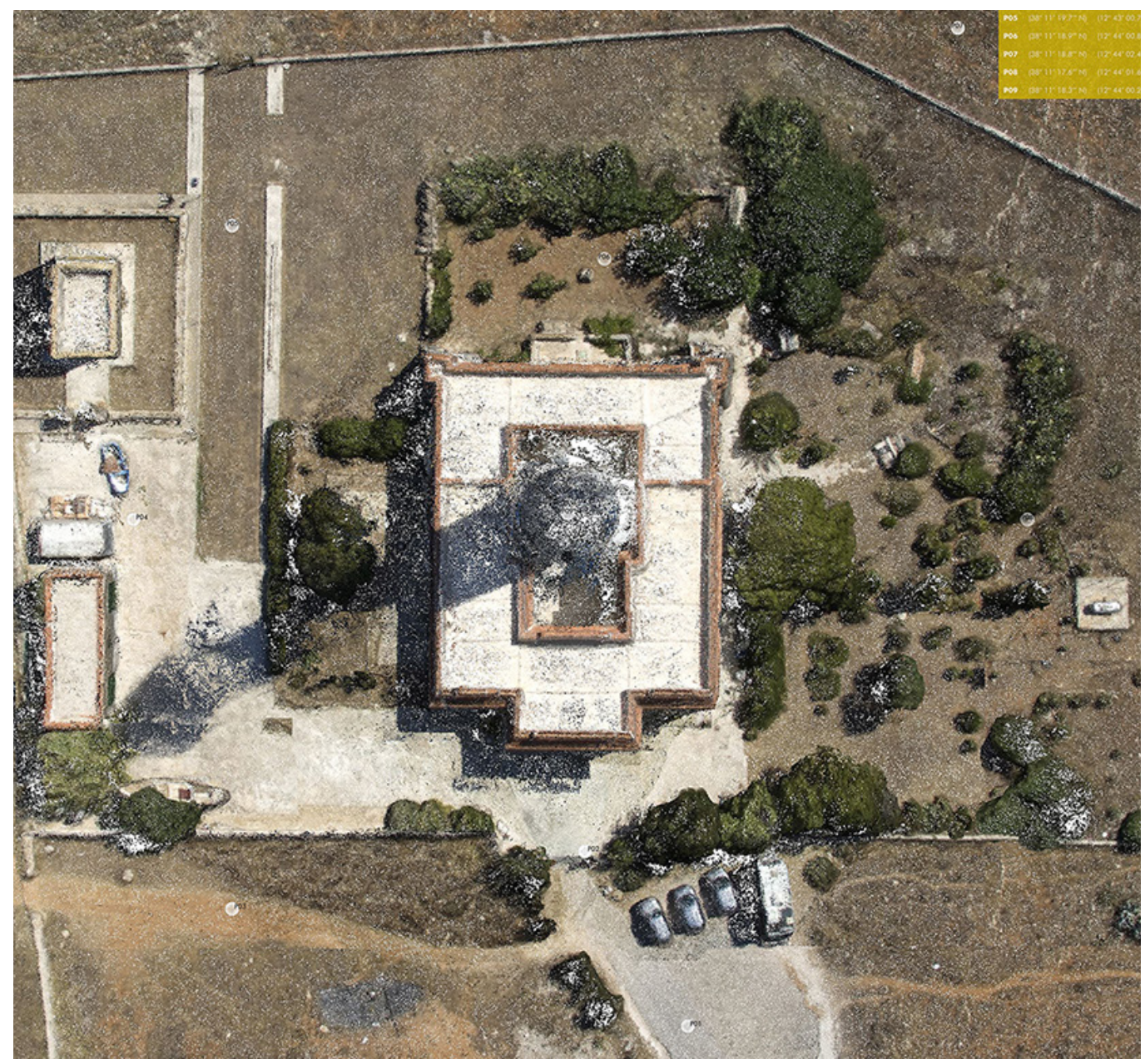




\section{Conclusioni e prospettive della ricerca: i fari come elementi di connessione e valorizzazione del paesaggio costiero Mediterraneo}

II faro, un tempo architettura quasi esclusivamente funzionale, sta diventando oggi l'elemento cardine attraverso cui intraprendere un percorso in grado di evidenziare i nodi fondamentali di una vasta rete di emergenze costiere, ponendo le basi per un'ipotesi di valorizzazione di tutta la costa italiana affacciata sul Mediterraneo e del suo patrimonio culturale e paesaggistico. La valorizzazione dei beni culturali, oggi, rappresenta un asset privilegiato per lo sviluppo e l'innovazione dell'intera comunità. In questa logica, in accordo con le linee guida promosse dalla comunità Europea e dall'Unesco [8], i modelli di sviluppo culture oriented hanno l'obiettivo di potenziare il valore del bene comune nelle sue molteplici caratterizzazioni e sono finalizzati allo sviluppo di dispositivi e sistemi di congiunzione in grado di ri-connettere le comunità attraverso il sapere, ridisegnando contemporaneamente i legami tra locale e globale, fra tradizione e innovazione, tra pubblico e privato.

I beni culturali sono il risultato di relazioni sociali. Essi accrescono il loro valore tanto più sono riconosciuti ed incorporati nella coscienza collettiva di una comunità. Si rende, dunque, necessario considerare la narrazione di luoghi unici e complessi, connessi tra loro, capaci di mettere in atto reciproche contaminazioni e, al netto della creazione di una fitta rete, d'instaurare un empowerment del proprio valore intrinseco. La creazione di piattaforme, dispositivi, metodologie si pongono come lo strumento ideale attraverso cui organizzare questo vasto patrimonio culturale, permettendone un'adeguata legittimazione del proprio valore-utilità, incorporandone la validità nei modi di vita contemporanei [Montella 2009].

Fig. I0. Rilievo fotogrammetrico aereo del faro di San Vito Lo Capo, vista assonometrica.

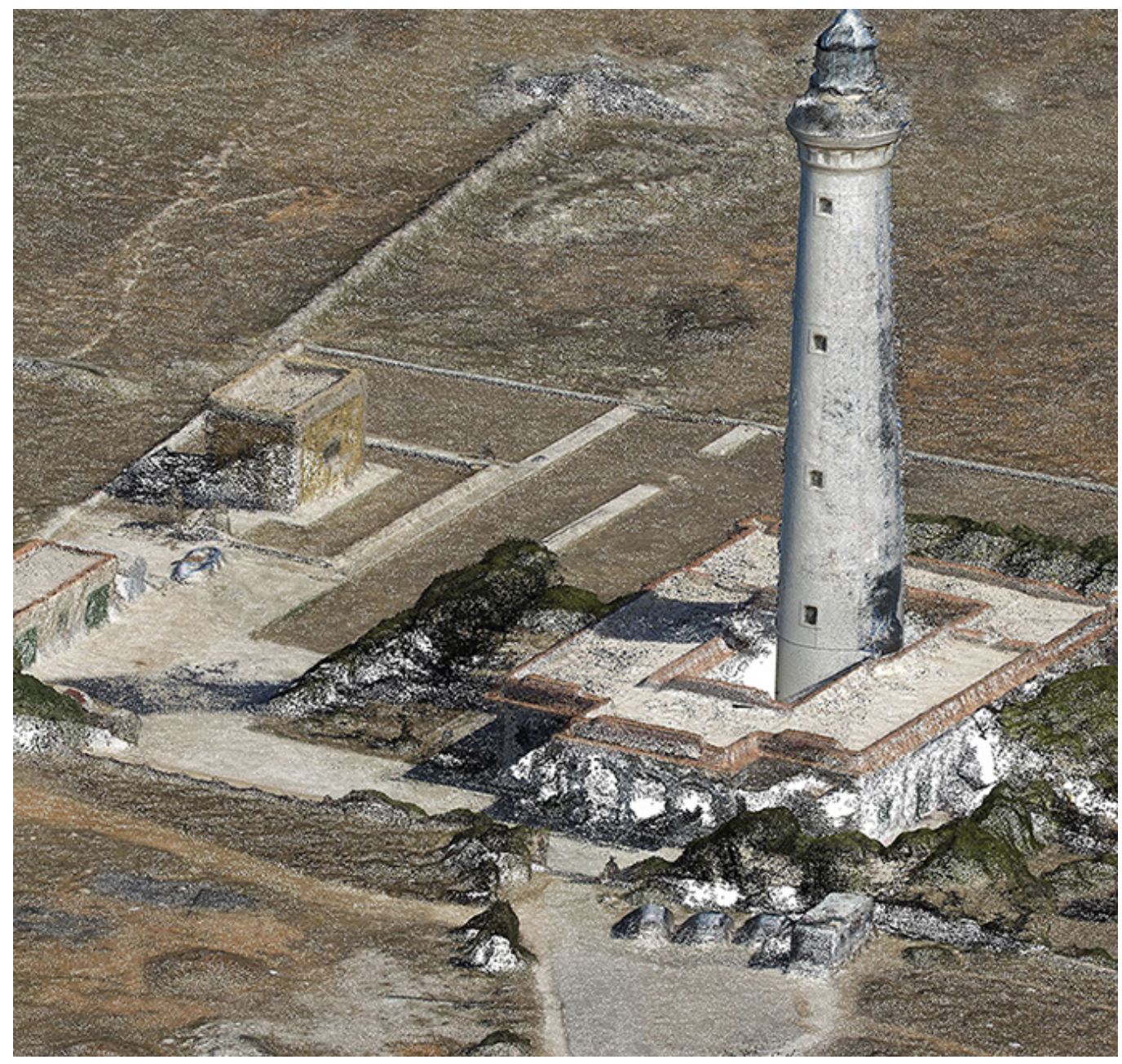


Fig. II. Rilievo fotogrammetrico terrestre del faro di San Vito Lo Capo restituzione dei prospetti.

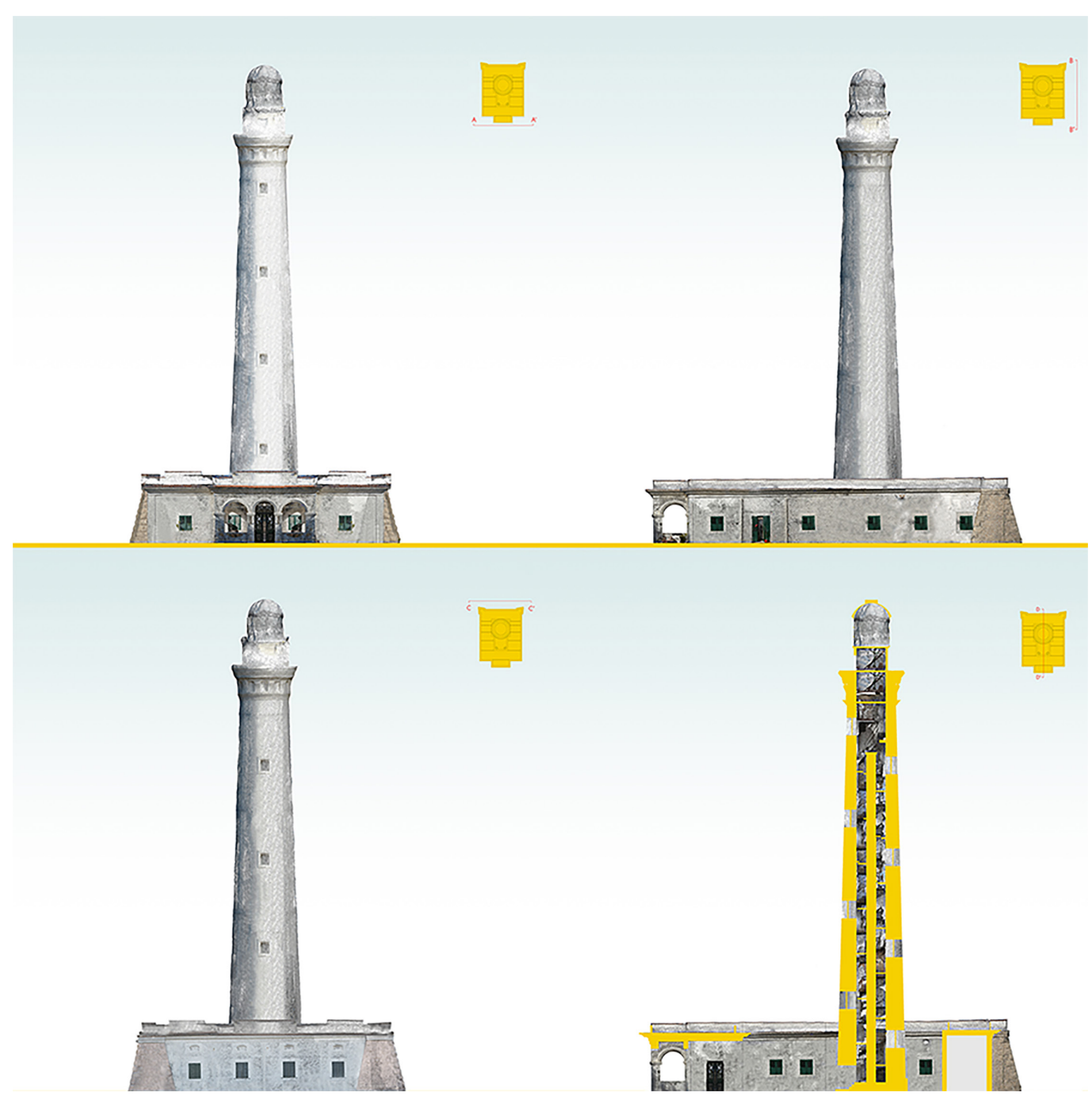

Note

[ I] Nel corso del paper ci si baserà sui principi dell'Universal Design, del Design for All e dell'inclusive design, strumenti ideali e stabilmente adottati per garantire l'accesso al patrimonio comune per il maggior numero di persone possibili.

[2] Numerosi sono stati i progetti realizzati dal MiBACT negli ultimi anni, volti al superamento dell'accessibilità fisica e sensopercettiva. Nell'era della 'società tecno-liquida e digitale' si mira alla realizzazione di progetti pilota per una 'accessibilità universale' [London Charter 2009 <http://www.londoncharter.org/>].

[3] Fissa gli impegni per lo sviluppo sostenibile da realizzare entro il 2030, individuando 17 Obiettivi (SDGs - Sustainable Development Goals) e 169 target.

[4] "Ogni paesaggio suscita due tipi di memorie - spiega l'etnologo e antropologo francese Marc Augè - "una memoria collettiva [...] che accoglie però anche un insieme infinito di singole immagini e di ricordi individuali" [Marc Augè 2017 ].

[5] Turri pone l'uomo-attore-spettatore come mediatore tra conoscenza ecologica e senso della memoria, di tutela e salvaguardia, di capacità di saper cogliere il senso che i paesaggi emanano [Turri 200l].

[6] Ovverosia l'individuo metà reale e metà immaginario.

[7] Le tecnologie ICT, profondamente pervasive, incidono direttamente ampliando la nostra esperienza reale dello spazio agito, sia esso fisico o digitale.

[8] UNESCO, World Conference on Cultural Policies, Mexico City, 26 luglio-6 agosto 1982. 


\section{Riferimenti bibliografici}

AA.W. (I873). Album dei fari del Regno d'ttalia. Roma: Ministero LL.PP.

Antinucci Francesco (2014). Comunicare nel museo. Roma-Bari: Laterza.

Marc Augè (20 17). I paesaggi sono fatti culturali :<https://www.che-fare.com/marc-auge-i-paesaggi-sono-fatti-culturali/?print=pdf>. Bartolomei Cristiana (2009). I fari d'ttalia.Vicenza: Magnamare edizioni.

Bartolomei Cristiana, Amoruso Giuseppe (2009). L'architettura dei fari italiani. Architecture of the italian lighthouses. Sicilia. Firenze: Alinea Editrice.

Biagetti Maria Teresa (2016). Un modello ontologico per l'integrazione delle informazioni del patrimonio culturale: CIDOC-CRM. In Italian Journal of Library \& Information Science, n. 7, vol. 3, pp. 43-77.

Brusaporci Stefano, Trizio llaria (20/3). La Carta di Londra e il patrimonio architettonico: riflessioni circa una possibile implementazione. In SCIRES-IT, n. 2, vol. 3, pp. 55-68.

Brusaporci Stefano, Maiezza Pamela (2018). Tra Storia e Memoria. Tecnologie avanzate per la (ri)definizione partecipativa del significato dei luoghi nella città storica. In Luigini Alessandro, Panciroli Chiara. Ambienti digitali per l'educazione all'arte e al patrimonio. Milano: FrancoAngeli, pp. 5 I-63.

Cervellini Francesco, Rossi Daniele (20 I I). Comunicare emozionando. L'edutainment per la comunicazione intorno al patrimonio culturale. In DisegnareCon, n. 8, vol. 4, pp. 48-65.

Ciastellardi Matteo (2012). Le architetture liquide. Dalla rete del pensiero al pensiero in rete. Milano: Led Edizioni Universitarie. EmplerTommaso (20 I7). ICT per il Cultural Heritage. Rappresentare, Comunicare, Divulgare. Roma: DEI - Tipografia Genio Civile.

Fatta Francesca (2002). Luci del Mediterraneo. I fari di Calabria e Sicilia. Soveria Mannelli: Rubbettino.

Grassini Aldo (2015). Per un'estetica della tattilità. Ma esistono dawero arti visive? Roma: Armando.

Jenkins Henry (2009). Culture partecipative e competenze digitali. Media education per il XXI secolo. Milano: Guerini e associati.

Lampis Antonio (20 I 8). Ambienti digitali e musei: esperienze e prospettive in Italia. In Luigini Alessandro, Panciroli Chiara. Ambienti digitali per l'educazione all'arte e al patrimonio. Milano: FrancoAngeli, pp. I I- I5.

Luigini Alessandro, Panciroli Chiara (20 I8). Ambienti digitali per l'educazione all'arte e al patrimonio. Milano: FrancoAngeli.

Luigini Alessandro (2017). Visual Storytelling Idee ed esperienze tra spazio, didattica e narrazione. In Luigini Alessandro. Lineis Describere. Sette seminari tra rappresentazione e formazione. Melfi: Libria.

Magnaghi Agostino, Bertuglia Cristoforo Sergio, Bertuglia Francesca (1999). II museo tra reale e virtuale. Roma: Riuniti.

Mancuso Stefania (2004). Per una metodologia della valorizzazione dei beni archeologici: analisi e prospettive in Calabria. Soveria Mannelli: Rubbettino.

Manfredini Camillo, Pescara Antonio (1985). Il libro dei fari italiani. Milano: Mursia.

Maniello Donato (20 I4). Realtà aumenta in spazi pubblici. Tecniche base di video mapping. Napoli: Le Penseur.

Mariotti Annamaria Lilla (2013). Fari. Roma:White Star.

Martini Berta (2016). II Museo Sensibile. Le tecnologie ICT al servizio della trasmissione della conoscenza. Milano: FrancoAngeli.

Montella Massimo (2009). Valore e valorizzazione del patrimonio culturale storico. Milano: Electa, 2009.

Morin Edgar (1958). Le cinéma ou l'homme imaginaire: Essai d'anthropologie sociologique. Milano: Minuit.

Ministero dei Beni e delle Attività Culturali e del Turismo (2017). Piano strategico di sviluppo del turismo. <https://www.senato.it/ service/PDF/PDFServer/BGT/0 I000578.pdf>.

Nucifora Sebastiano (2006). Contrassegni verticali. Una rilettura del paesaggio costiero siciliano attraverso l'architettura dei fari. Reggio Calabria: liriti editore.

Trimarchi Michele (20 I0). Economia e cultura. Organizzazione e finanziamento delle istituzioni culturali. Reggio Calabria: FrancoAngeli.

Turri Eugenio (200 I). Il paesaggio come teatro. Dal territorio vissuto al territorio rappresentato.Venezia: Marsilio.

Venturi Ferriolo Massimo (2009). Percepire paesaggi. La potenza dello sguardo. Torino: Bollati Boringhieri.

\section{Autori}

Sonia Mollica, Università degli Studi Mediterranea di Reggio Calabria, sonia.mollica@virgilio.it

Andrea Marraffa, Università degli Studi Mediterranea di Reggio Calabria, andreamarraffa89@yahoo.it

Per citare questo capitolo: Mollica Sonia, Marraffa Andra (2020). La riconnessione delle città costiere: La rete dei fari italiani/The reconnection of coastal cities. The network of Italian lighthouses. In Arena A., Arena M., Brandolino R.G., Colistra D., Ginex G., Mediati D., Nucifora S., Raffa P. (a cura di). Connettere. Un disegno per annodare e tessere. Atti del $42^{\circ}$ Convegno Internazionale dei Docenti delle Discipline della Rappresentazione/ Connecting. Drawing for weaving relationships. Proceedings of the 42th International Conference of Representation Disciplines Teachers. Milano: FrancoAngeli, pp. 3553-3576. 


\title{
The Reconnection of Coastal Cities. The Network of Italian Lighthouses
}

\author{
Sonia Mollica \\ Andrea Marraffa
}

Abstract

The paper aims to clarify a study methodology for the enhancement of cultural heritage, in line with the 2019/2023 regional strategic tourism development plan of the Sicily region, experimented during the development of a research, starting from the analysis and the study of the network of lighthouses in the Album dei fari of Italy, dating back to the post-unitary period. For an effective narration and visualization of places, according to a theoretical plan, new technologies have been put in place for the use of cultural heritage, such as, for example, video mapping, for the creation of a new Grand Tour of the places. The project aims to encourage and enhance the Sicilian tourist offer, with a view to a broader organic program that provides for a more inclusive [I], sustainable and culturally accessible territorial development. We consider the narration of unique and complex places, connected to each other, capable of implementing mutual contaminations and, net of the creation of a dense network, of establishing an empowerment of one's intrinsic value which, at this point, will no longer equal the sum of the individual coastal identities.

Keywords

Album dei fari of Italy, identity of the places, re-connection, Grand-Tour, video mapping.

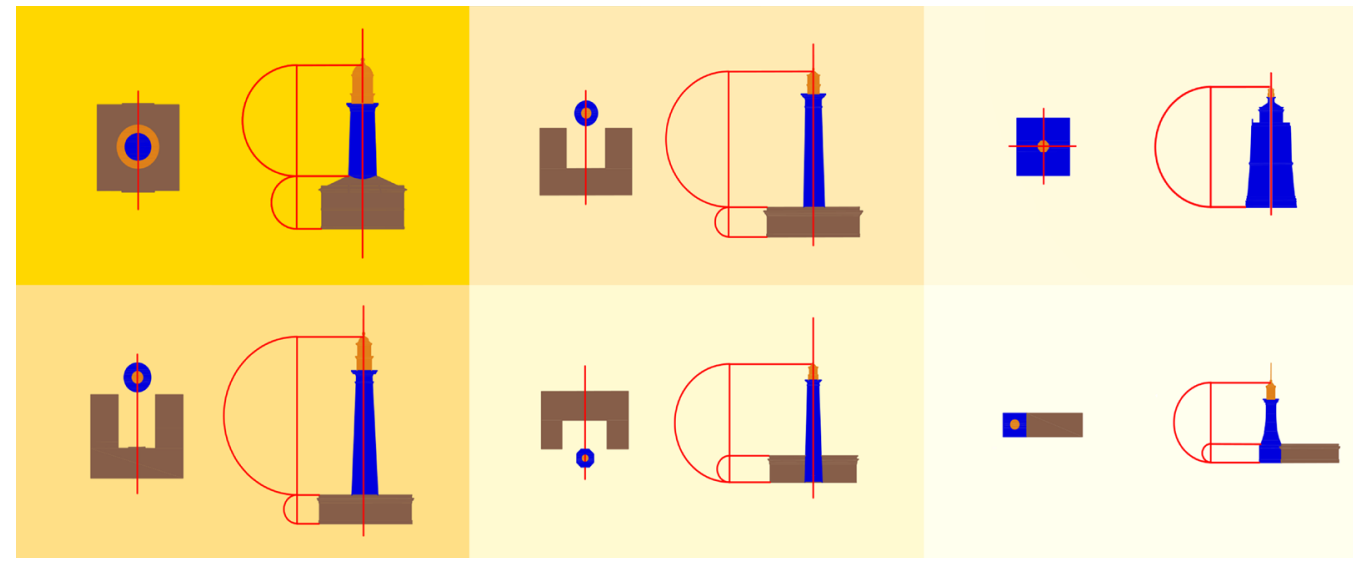


Fig. I. Study and analysis based on the cartography present in the Album dei Fari of Italy.
Fig. 2. Three-dimensional models based on the projects in the Album de fari of Italy. Unrolling of the Italian coast.

\section{Introduction. Story of the Italian lighthouses: from the myth to the ruin}

The figure of the lighthouse has always intrigued the collective imagination, the birth of these architecture dates back to very distant times and their transformation goes hand in hand with the progress of navigation technologies. Already Homer in the XIX book of the lliad compared the shimmer of Achilles' shield to one of those fires that rise from the heights and that make the way safe for sailors, but, the concept of 'lighthouse' was born only in 300 $\mathrm{BC}$ with the Colossus of Rhodes and the lighthouse of Alexandria.

The Roman Empire saw the birth of the first stone towers with a fire lit at the top. This interval was followed by a dark period for the construction of the lighthouses, which ended only during the modern age, during which the lighthouse towers regained a new sighting force.

With the industrial revolution, then, the signaling systems change thanks to the technological innovations of those years, the towers are transformed into lighthouses, formed by symmetrical bodies, from turrets and lanterns, populating the most suggestive places of the sea coasts with luminous signals propagated by 'Fresnel' lenses, operated by the farists who lived there.

Today, the advent of automated lantern lighting systems marks a further evolution of these artifacts which, while maintaining the high symbolic and identity value, no longer see, in many cases, their use as a home, causing the sudden and relentless transformation of buildings into wrecks of history, fragments of memory now gone.

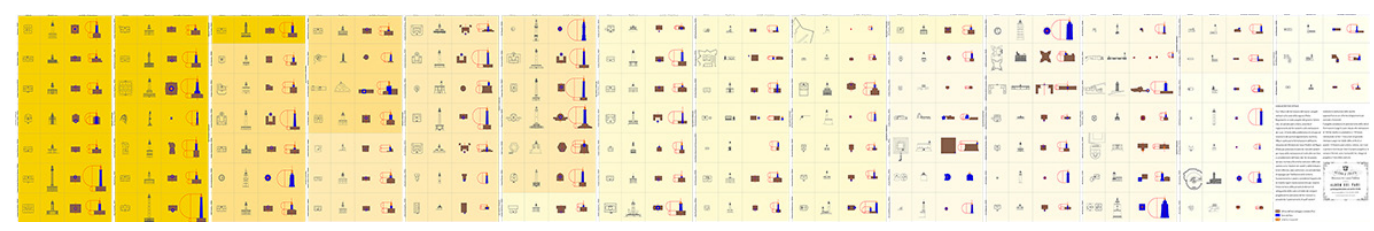

The Album dei fari of Italy 3.0 and Research methodology: the new digital connections

The theme of accessibility [2] to the cultural heritage and the enhancement of the art and the artistic heritage, appear as pillars of what are the main programs including: the 2019/2023 regional strategic development plan for tourism in the Sicily region, the 2030 Agenda [3] and the main ERC sectors. Based on them we want to undertake and dissect a research developed at the Mediterranean University of Reggio Calabria, entitled The lighthouse of San Vito Lo Capo: from the network of the Italian lighthouses to the relief of the architectural artifact, for a Grand Tour of the Sicilian coasts, based on the concept of network and on the study of the coastal building.

In order to satisfy an increasingly growing and articulated demand for tourist-cultural routes, the network organization proves to be an effective and successful way. The study towards the creation of a replicable reticular methodology identifies as a first research phase the re-reading of the coastal artefacts, listed and filed in the Album dei fari of Italy, the first organic collection of these architectures, made in the aftermath of the Unity of the Kingdom of Italy. The Album dei fari represents a vast project of the Italian government which provided for the drafting of a program aimed at the construction of new lighthouses and the improvement of the existing ones which formalization constitutes the formalization of the initiative undertaken by the Ministry of Public Works of the Kingdom of Italy to enhance the range of existing structures through the construction of many other light towers to complete the entire network.

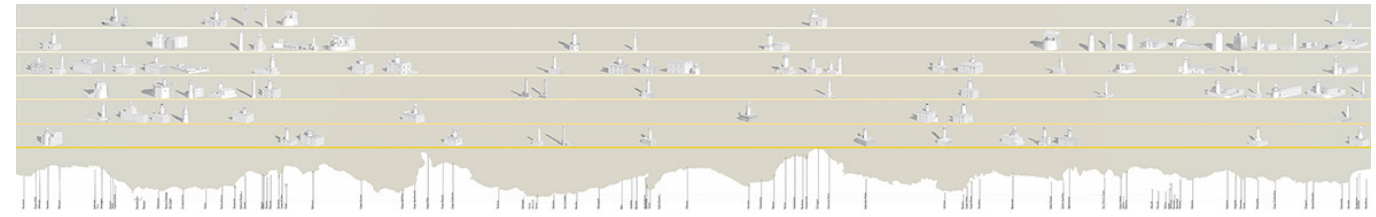




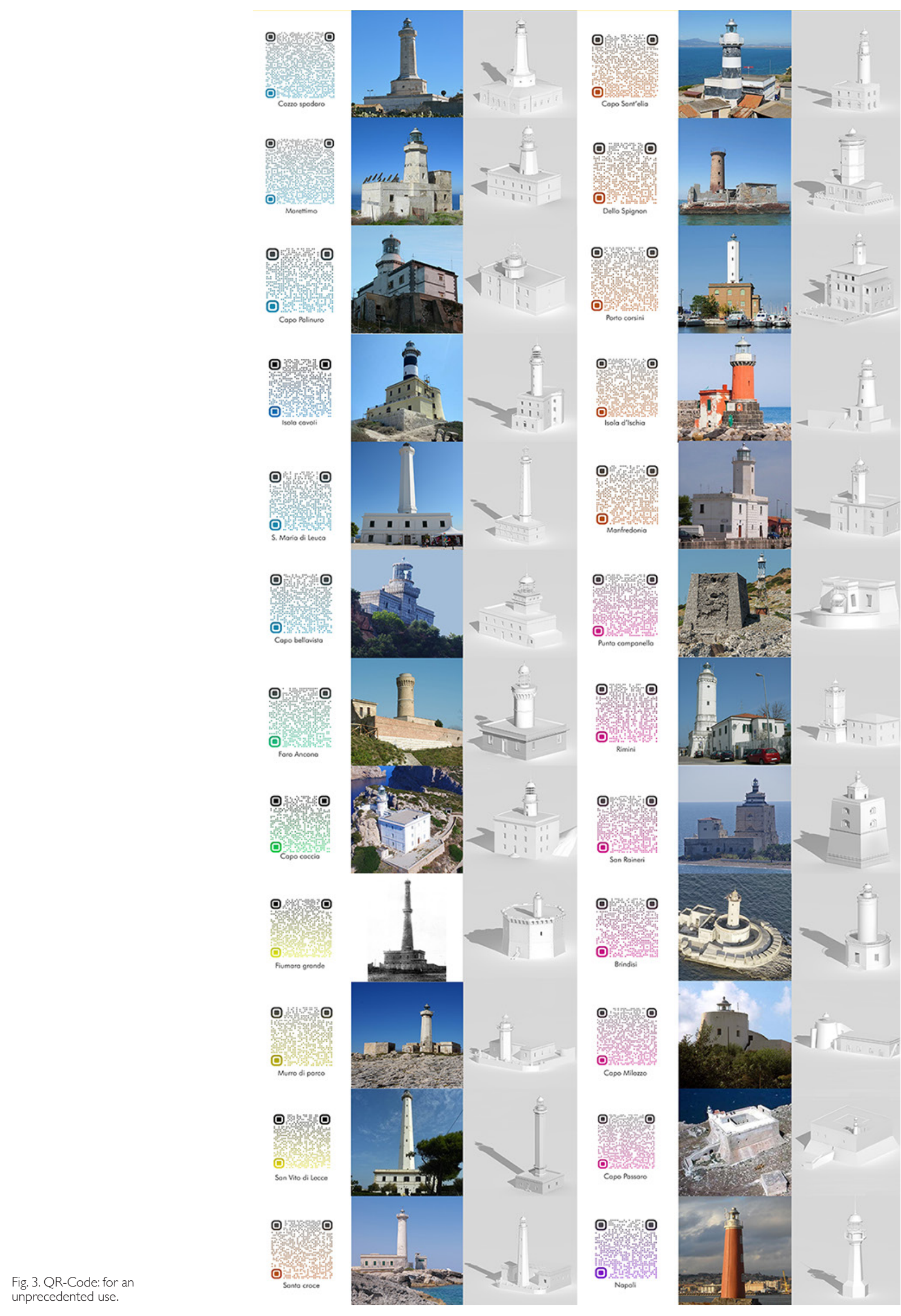


The government, however, was unable to carry out a construction project of this bulk, in fact, the formal changes between the design drawings of the time and today's architectural artifact are clearly visible.

In order to implement what is proposed as a research methodology based on the re-reading of the coastal identity points, in order to create cognitive paths, it was necessary to elaborate as a first research phase the redesign of what are the geometries of the ninety-four lighthouses implemented in the official documentation, in order to extrapolate their modules and geometries, establishing a simpler formal comparison between coastal architectures (fig. I).

The redesign was preparatory for the development of three-dimensional models formulated on the basis of the documentation in the Album dei fari and on various photographic references, thanks to which a level of architectural detail was achieved capable of transmitting what are the volumetric ratios and spatial architecture of the post unitary period according to a new vision. The second phase, therefore, brings into play exclusive arguments that find their explanatory representation in the long Italian coast deployed according to the 'unrolling' [Nucifora 2006] method. The latter is a graphic device that uses rotation points coinciding with the headlights, which, net of completing the rotation, will lie on a vertical line. To better understand the representative system of the drawing, a double reading was necessary, in fact, the layout is also divided according to horizontal lines, lines with different gradations of color, in order to identify with a single glance the lighthouses orders, established according to the range of the light of the lamp (fig. 2).

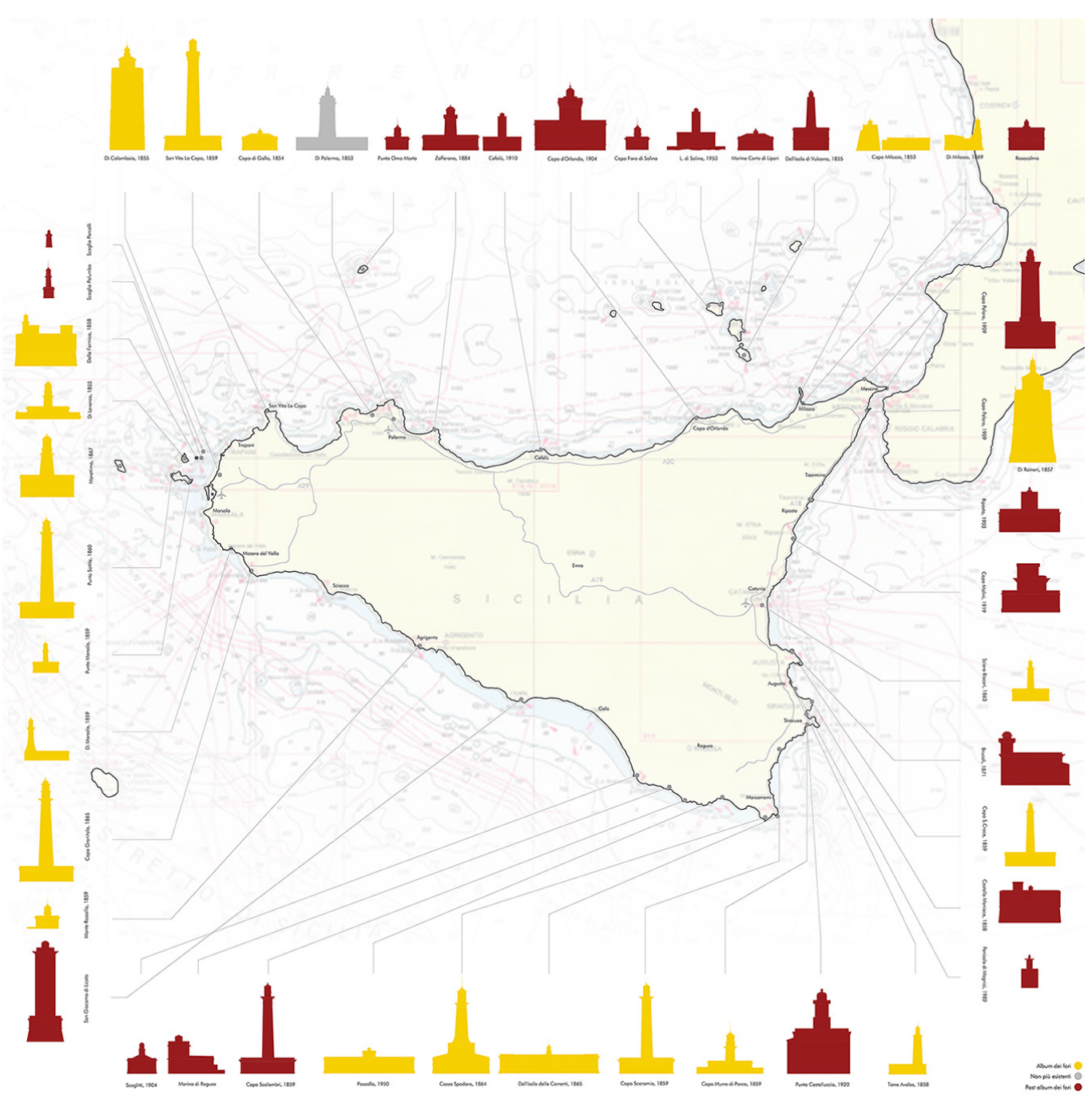


In order to make the three-dimensional models usable in their entirety, each of them has been associated with a QR-code (fig. 3), through which it is possible to be directed to an online IT platform where you can read the digital models in three dimensions. Here, the models lend themselves to total reading: it is possible to go around the architecture, enter inside it and choose different viewing modes. The result of the digitization and three-dimensional modeling of all ninety-four coastal artefacts is the prerequisite on which the study methodology outlined here is based, for a project for the networking of coastal heritage through which to develop thematic paths of mending and valorising the territory.

The methodology, at this point, translates into what is the third phase, determined by the 'recognition' of the state of affairs of the coastal artifacts with respect to the projects outlined in the Album dei fari. This analysis revealed that about half of the documented lighthouses underwent radical changes compared to the project planned during the Unification of Italy and, above all, that as many lighthouses were designed and built in a subsequent period (fig. 4). This denotes the sign of a constantly changing landscape [4] and a necessary awareness of the fragility of these artifacts that are little respected and little considered for their historical, landscape and architectural value.

With the recognition of all today's coastal structures, in this exclusively Sicilian proposal, and their spatial and material peculiarities, efforts have been made to increase the tourist flows towards these evocative territories and to enhance their recognition of their identity and cultural value. Thematic paths have therefore been hypothesized to make the connections between the conspicuous points of the coastal territory more explicit; different paths that

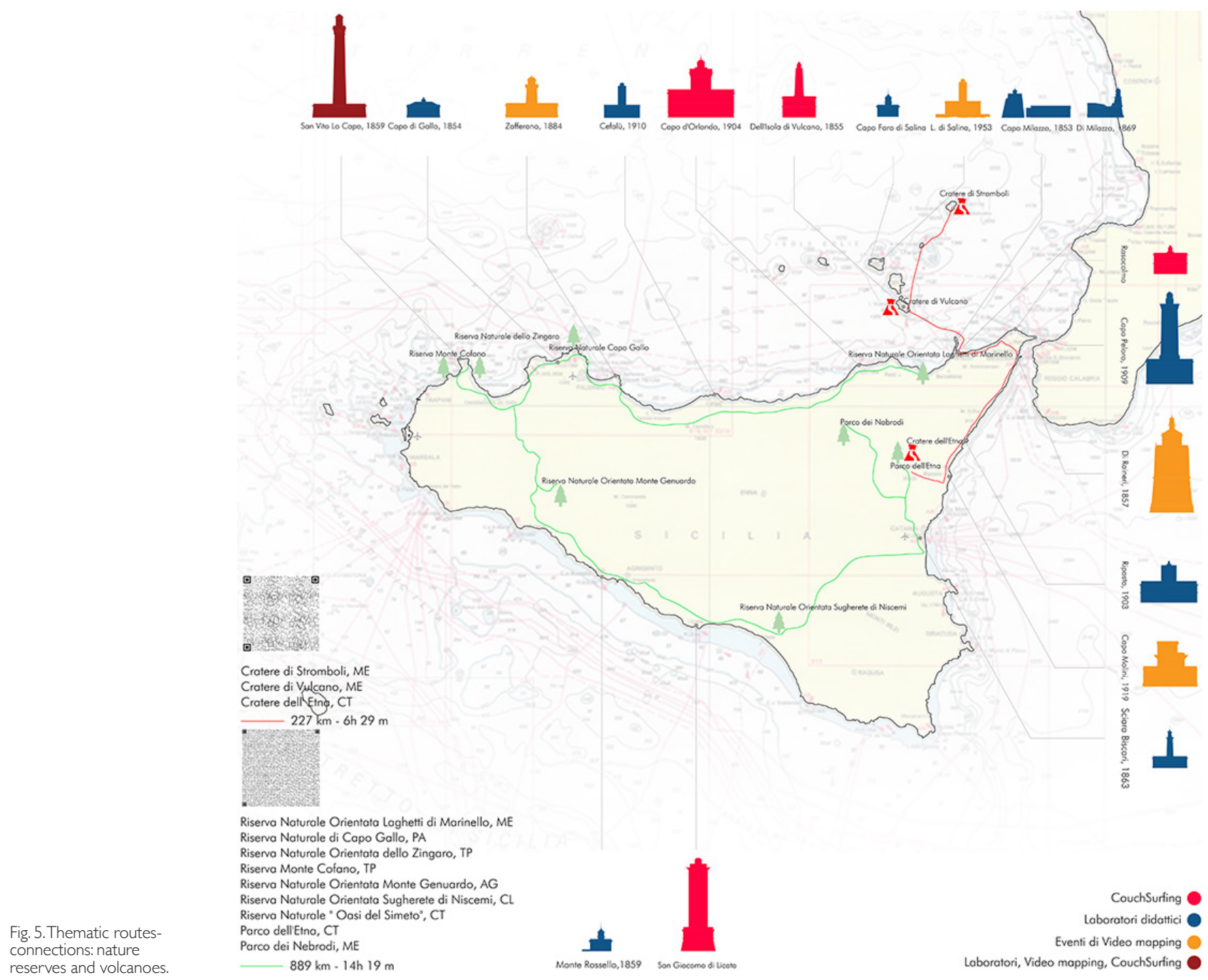


can adapt to different types of tourist users: sports tourism -nature reserves and volcanoes (fig. 5), art tourism- baroque (fig. 6), seasonal tourism - beaches (fig. 7), food and wine tourism (fig. 8). These represent only some of the possibilities through which the connections between the parts of the territory unfold and through which it is possible to create a pretext that finds as its ultimate goal the enhancement and development of the intrinsic value of the common heritage.

In their representation, the paths carried out are flanked by QR-codes through which they can be redirected towards a georeferenced itinerary, easy to use even for those less accostumed to technology. The routes have been chosen in order to make stable tourism, therefore not seasonal, as often happens in the southern territories, and to make them attractive to all age and interest groups. For this reason, it is also possible to intersect the different network paths, offering an increasingly personalized and customizable level of use. Within the thematic strategy adopted, the lighthouses become the theater of different types of use, always different according to the routes; here is the conclusion of this trip in the Sicilian coastal identities, in their new economic and social reuse. In fact, the coastal building is inserted gently into a tourist network, making use of the digital entertainment systems: video mapping; or again, we rediscover what are the social and cultural values handed down by ancient crafts, spending a night in a lighthouse together with its guardian certainly represents a unique experience still totally unexplored in Italy. These are the prerequisites for a tourist idea, albeit in an embryonic state, through which to gain momentum towards the rediscovery of new readings of the territory.

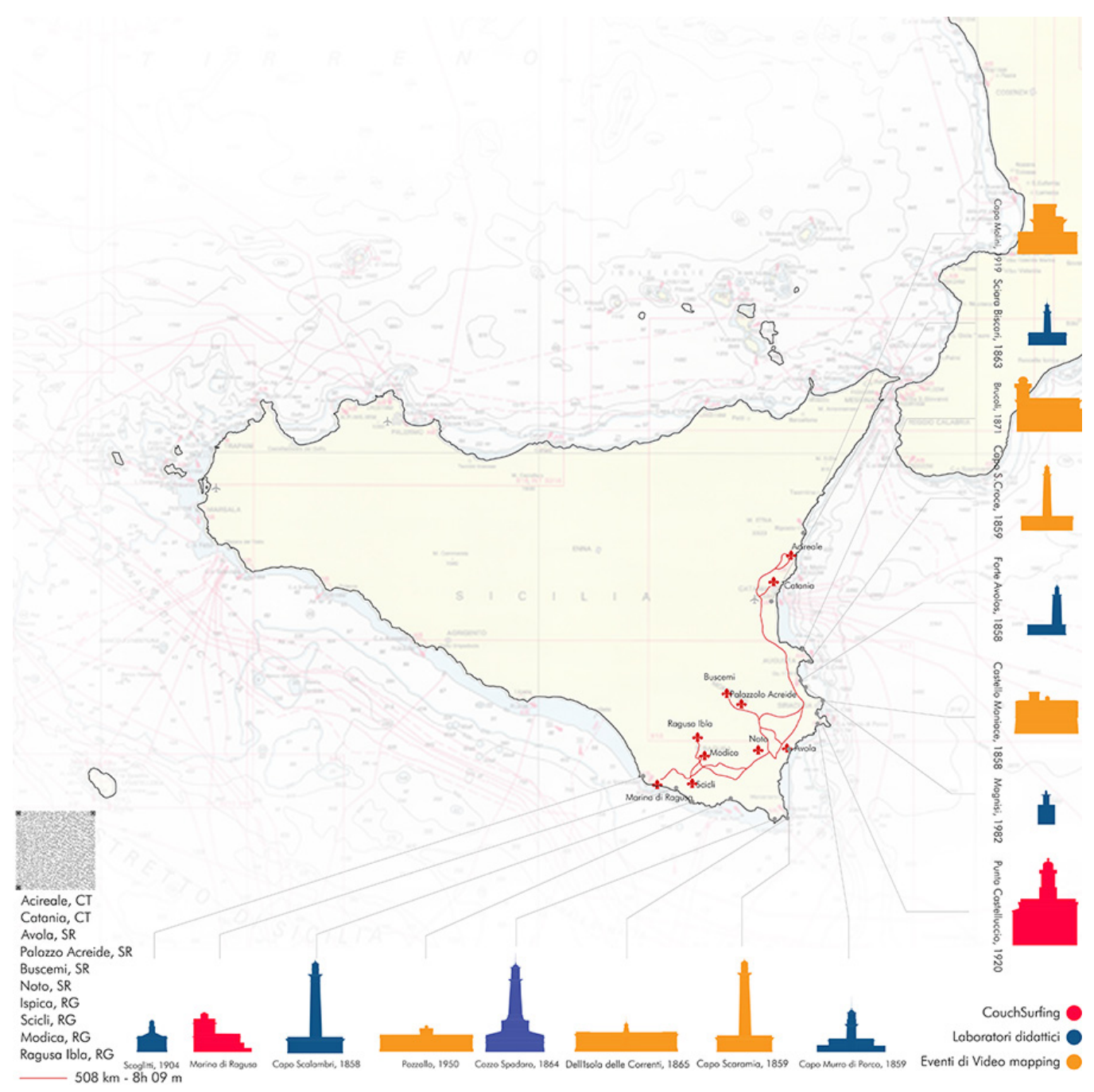




\section{Ancient identities of places, new narratives, unedited reconnections}

The study on coastal artefacts, and in particular on lighthouses, brings to itself a reflection on the great evocative sense that these exercise on the memory of each of us. Following a path means, in a certain sense, exploring what is the identity of a place, hypothesizing its metamorphosis, understanding its continuous changes and questioning the reason that caused them. In accordance with this idea, in order to give a more correct intended use within these network paths, we wanted to take into consideration a specific Sicilian coastal identity, the lighthouse located in San Vito Lo Capo, thanks to which through the execution of a careful integrated survey campaign, it was possible to study the different historical and spatial modifications.

The analysis of the state of affairs of the architectural settlement, carried out on the basis of a survey campaign performed with an aerial and terrestrial photogrammetric system (figs. 9-II), returned an updated and reliable map of the place on the identity and hospitality potential of the lighthouse. It is on these cardinal points that the criterion for selecting the destinations of use of the lighthouses in the thematic itineraries is based. The lighthouse of San Vito lo Capo is part of this network as a lighthouse of impetuous cultural and historical importance, for this reason, also thanks to its great offer in terms of architectural spaces, it makes it possible to mix different uses in the development of all the paths of western Sicily.

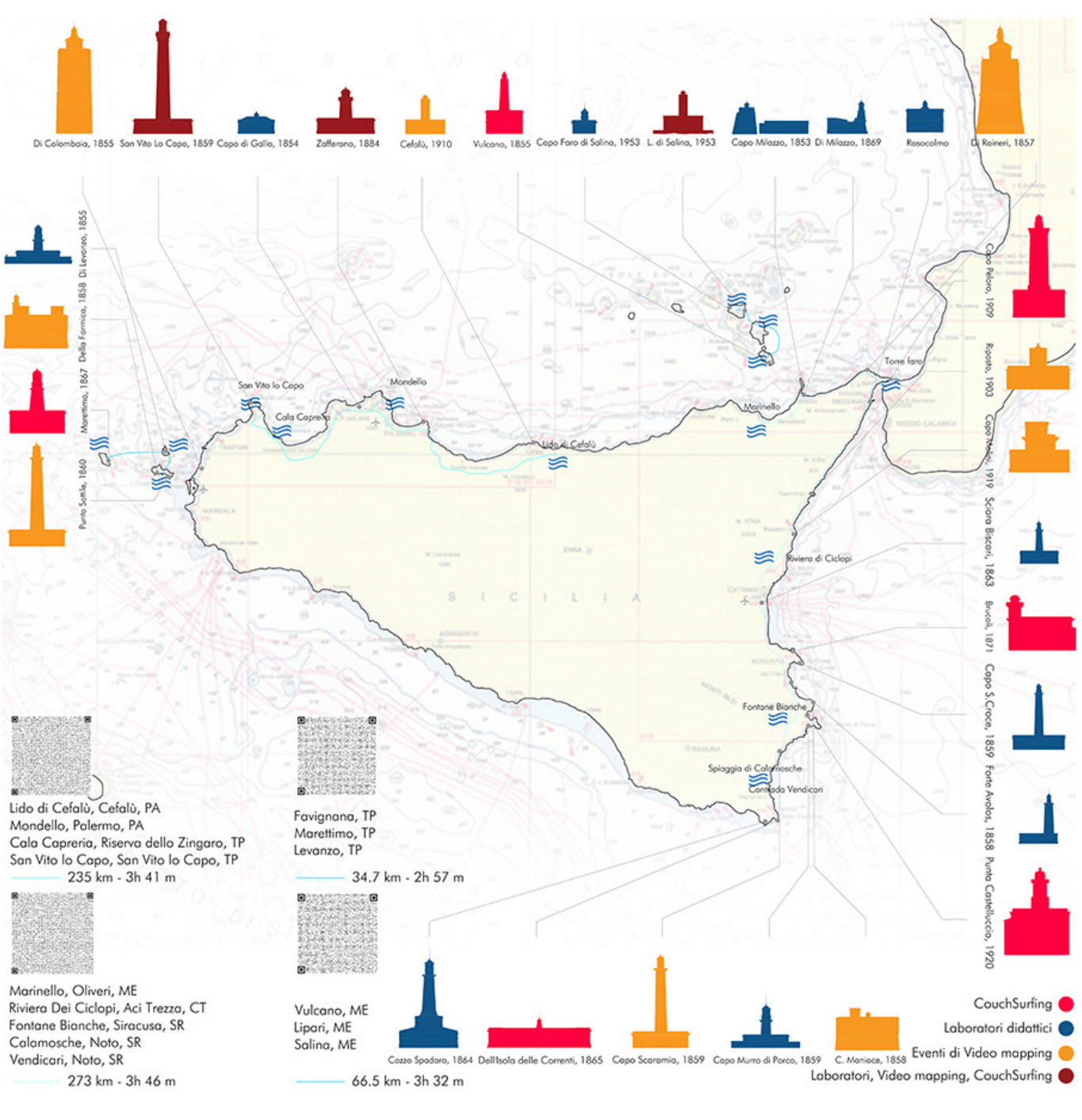


The playful aspect, which sees it as a great protagonist, thanks to the lantern that stands in the sky with its forty-two meters high, is intertwined with what is the fascinating routine of the lighthouse itself, being in contact face to face with the keeper of legends and myths. In fact, every coastal identity welcomes ancient stories, the charm of an unknown reality. The reconnection of myths corresponds to the reconnection of places, to the creation of a dense plot that links history to the landscape, based on what is visibility, temporality, accessibility and narration [Venturi Ferriolo 2009]. Strong is the bond that unites, therefore, the myth, the story, the narration and the landscape. A continuous game opens between event and mutation, narration and story. The succession of events always creates new scenarios to be codified, in which their perception always reveals itself as an organization of perceptual data, and not only, this is what according to Morin with his homme imaginaire [6], feeds the dualities, strengthens the connections, stimulates the union between real and imaginary.

Basically, the comparison between 'history' and 'memory' is highlighted, a field where digital technologies and ICT (Information and Communications Technology) can play a fundamental role.

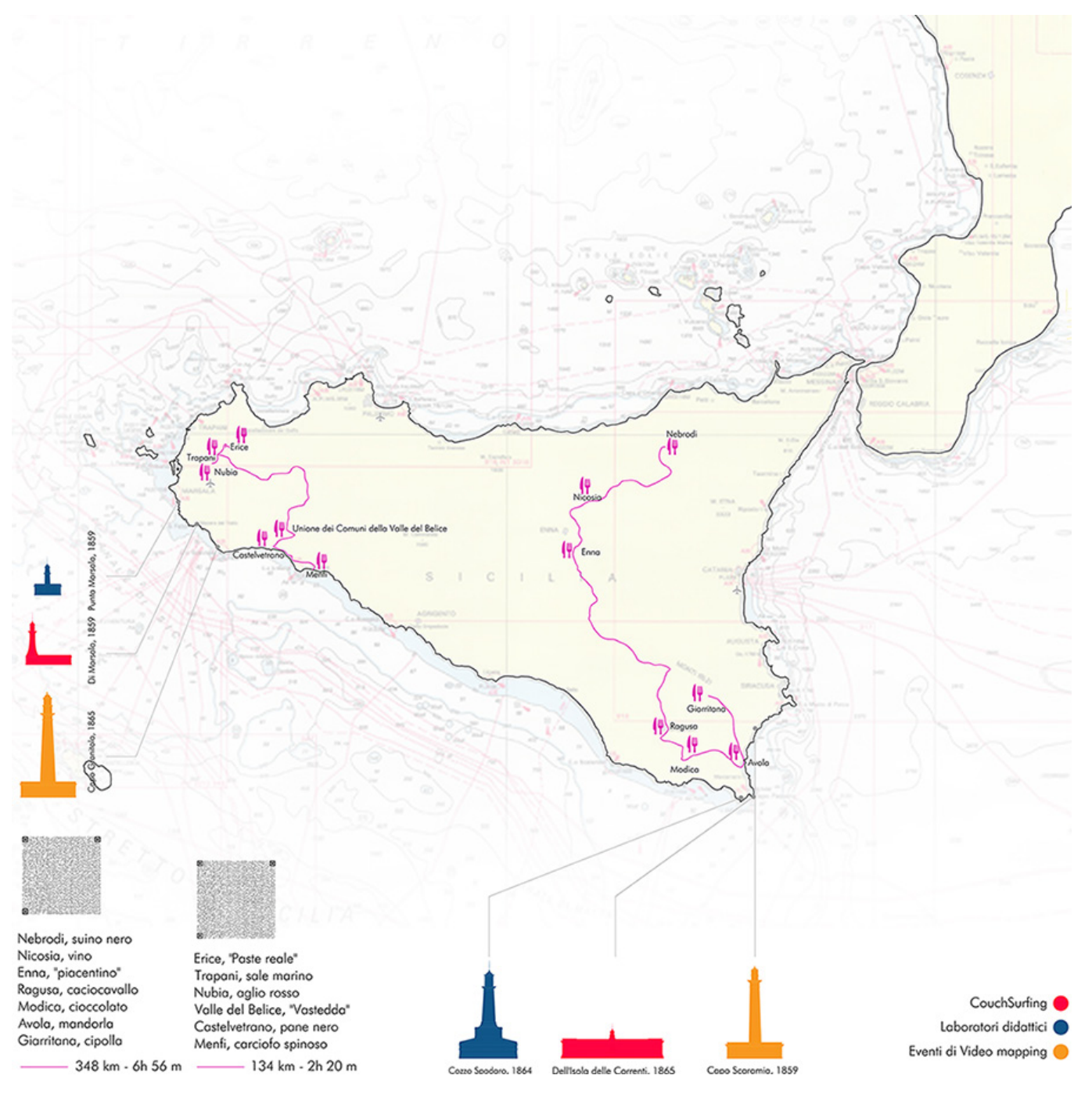




\section{The potential of ICT techniques for reconnecting places: new strategies for cultural inclusion}

In recent years, the cultural sphere has taken on increasingly turbulent dynamics, often subject to sudden transformations. Cultural institutions, in order to overcome the gap existing between the use and the offer offered, and in order to create ever new and imaginative visions, can use ICT [7], in order to improve accessibility, communication and under standing. There are many actions that can be adopted for the enhancement and promotion of the common heritage, which lay their foundations on an increasingly articulated and integrated territorial offer on different levels and contexts of experience, through which it is necessary to set up network, connection and enhancement of other territorial resources.

The network proposed here, in fact, identifies its design completion, as well as its mix between the tangible and intangible universe, in what wants to be the most immersive and suitable technique for multisensory and multilevel use: video mapping. Augmented reality, in contrast to virtual reality, gives the observer additional information compared to what the human eye can perceive, and makes it possible to integrate material physical reality with new immaterial cultural and historical knowledge. Through this technique, in fact, it is possible to tell and paint the spatial changes of a place with light, to illustrate imaginative stories of networks and paths, to narrate myths and legends of which these architectures are rich.

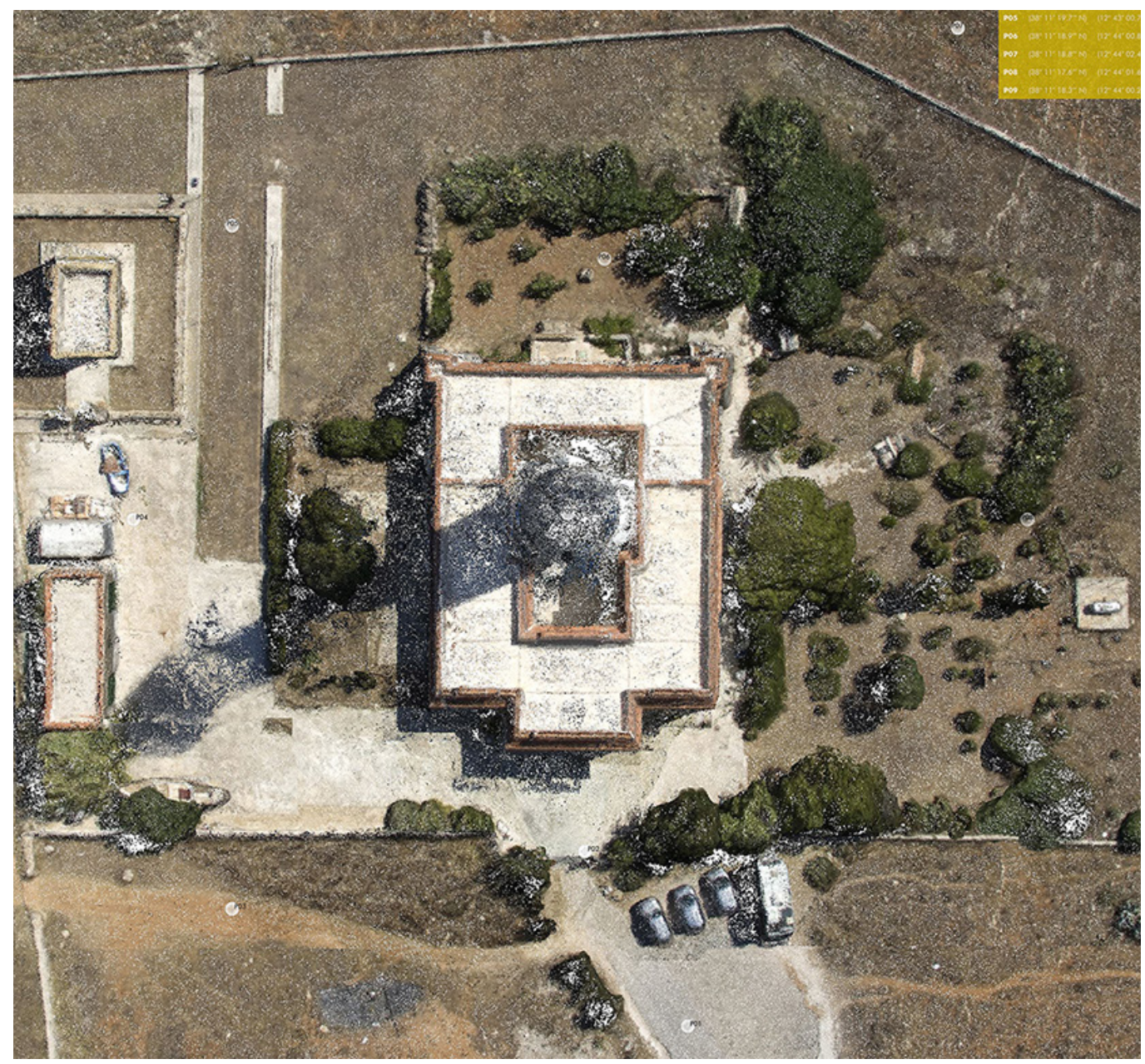




\section{Conclusions and perspectives of the Research: the lighthouses as elements of connection and enhancement of the Mediterranean coastal landscape}

The lighthouse, once an almost exclusively functional architecture, is now becoming the key element through which to embark on a path capable of highlighting the fundamental nodes of a vast network of coastal emergencies, laying the foundations for a hypothesis of valorisation of the entire Italian coast overlooking the Mediterranean and its cultural and landscape heritage. The enhancement of cultural heritage today represents a privileged asset for the development and innovation of the entire community. In this logic, in accordance with the guidelines promoted by the European community and by UNESCO [8], the culture oriented development models aim to enhance the value of the common good in its multiple characterizations and are aimed at the development of devices and systems of conjunction capable of re-connecting communities through knowledge, redesigning at the same time the links between local and global, between tradition and innovation, between public and private.

Cultural heritage is the result of social relationships. They increase their value the more they are recognized and incorporated into the collective consciousness of a community. It is therefore necessary to consider the narration of unique and complex places, connected to each other, capable of implementing mutual contaminations and, net of the creation of a dense network, of establishing an empowerment of one's intrinsic value. The creation of platforms, devices, methodologies is the ideal tool through which to organize this vast cultural heritage, allowing an adequate legitimation of its value-utility, incorporating its validity in contemporary ways of life [Montella 2009].




Fig. II.Terrestrial photogrammetric survey of the lighthouse of San Vito Lo Capo, restitution of the elevations.

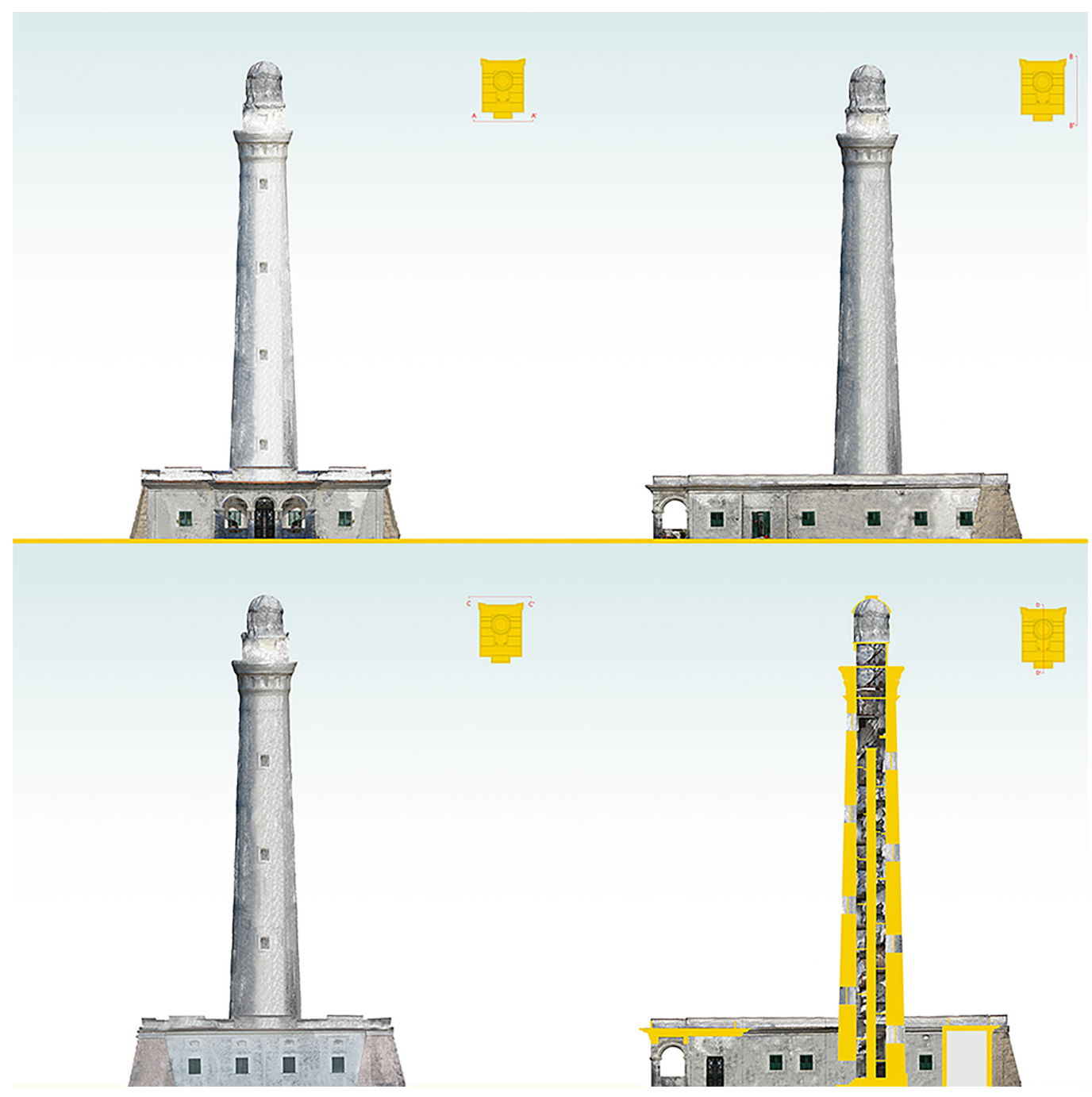

Notes

[I] In the course of the paper, we will base ourselves on the principles of Universal Design, Design for All and inclusive design, ideal and permanently adopted tools to guarantee access to the common heritage for as many people as possible.

[2] Numerous projects have been carried out by MiBACT in recent years, aimed at overcoming physical and sensoryperceptive accessibility. In the era of the 'techno-liquid and digital society', the aim is to create pilot projects for "universal accessibility" [London Charter 2009, <http://www.londoncharter.org/>]

[3] It sets the commitments for sustainable development to be achieved by 2030, identifying 17 Objectives (SDGs - Sustainable Development Goals) and 169 targets.

[4] "Each landscape elicits two types of memories - explains the French ethnologist and anthropologist Marc Augè - a collective memory $[\ldots]$ which however also includes an infinite set of individual images and individual memories" [Marc Augè $2017]$.

[5] Turri places man-actor-spectator as mediator between ecological knowledge and sense of memory, of protection and safeguard, of ability to know how to grasp the meaning that landscapes emanate [Turri 200 I].

[6] That is, the person half real and half imaginary.

[7] ICT technologies, deeply pervasive, directly affect expanding our real experience of the acted space, be it physical or digital.

[8] UNESCO, World Conference on Cultural Policies, Mexico City, 26 July-6 August 1982. 


\section{References}

AA.W. (I873). Album dei fari del Regno d'ttalia. Roma: Ministero LL.PP.

Antinucci Francesco (20 I4). Comunicare nel museo. Roma-Bari: Laterza.

Marc Augè (20 17). I paesaggi sono fatti culturali :<https://www.che-fare.com/marc-auge-i-paesaggi-sono-fatti-culturali/?print=pdf>. Bartolomei Cristiana (2009). I fari d'ttalia.Vicenza: Magnamare edizioni.

Bartolomei Cristiana, Amoruso Giuseppe (2009). L'architettura dei fari italiani. Architecture of the italian lighthouses. Sicilia. Firenze: Alinea Editrice.

Biagetti Maria Teresa (2016). Un modello ontologico per l'integrazione delle informazioni del patrimonio culturale: CIDOC-CRM. In Italian Journal of Library \& Information Science, n. 7, vol. 3, pp. 43-77.

Brusaporci Stefano, Trizio llaria (20/3). La Carta di Londra e il patrimonio architettonico: riflessioni circa una possibile implementazione. In SCIRES-IT, n. 2, vol. 3, pp. 55-68.

Brusaporci Stefano, Maiezza Pamela (2018). Tra Storia e Memoria. Tecnologie avanzate per la (ri)definizione partecipativa del significato dei luoghi nella città storica. In Luigini Alessandro, Panciroli Chiara. Ambienti digitali per l'educazione all'arte e al patrimonio. Milano: FrancoAngeli, pp. 5 I-63.

Cervellini Francesco, Rossi Daniele (20I I). Comunicare emozionando. L'edutainment per la comunicazione intorno al patrimonio culturale. In DisegnareCon, n. 8, vol. 4, pp. 48-65.

Ciastellardi Matteo (20 I2). Le architetture liquide. Dalla rete del pensiero al pensiero in rete. Milano: Led Edizioni Universitarie.

EmplerTommaso (20 I7). ICT per il Cultural Heritage. Rappresentare, Comunicare, Divulgare. Roma: DEI - Tipografia Genio Civile.

Fatta Francesca (2002). Luci del Mediterraneo. I fari di Calabria e Sicilia. Soveria Mannelli: Rubbettino.

Grassini Aldo (2015). Per un'estetica della tattilità. Ma esistono dawero arti visive? Roma: Armando.

Jenkins Henry (2009). Culture partecipative e competenze digitali. Media education per il XXI secolo. Milano: Guerini e associati.

Lampis Antonio (20 | 8). Ambienti digitali e musei: esperienze e prospettive in Italia. In Luigini Alessandro, Panciroli Chiara. Ambienti digitali per l'educazione all'arte e al patrimonio. Milano: FrancoAngeli, pp. I I- I5.

Luigini Alessandro, Panciroli Chiara (20।8). Ambienti digitali per l'educazione all'arte e al patrimonio. Milano: FrancoAngeli.

Luigini Alessandro (2017). Visual Storytelling Idee ed esperienze tra spazio, didattica e narrazione. In Luigini Alessandro. Lineis Describere. Sette seminari tra rappresentazione e formazione. Melfi: Libria.

Magnaghi Agostino, Bertuglia Cristoforo Sergio, Bertuglia Francesca (1999). II museo tra reale e virtuale. Roma: Riuniti.

Mancuso Stefania (2004). Per una metodologia della valorizzazione dei beni archeologici: analisi e prospettive in Calabria. Soveria Mannelli: Rubbettino.

Manfredini Camillo, Pescara Antonio (1985). Il libro dei fari italiani. Milano: Mursia.

Maniello Donato (2014). Realtà aumenta in spazi pubblici. Tecniche base di video mapping. Napoli: Le Penseur.

Mariotti Annamaria Lilla (20 I3). Fari. Roma:White Star.

Martini Berta (20 I 6). II Museo Sensibile. Le tecnologie ICT al servizio della trasmissione della conoscenza. Milano: FrancoAngeli.

Montella Massimo (2009). Valore e valorizzazione del patrimonio culturale storico. Milano: Electa, 2009.

Morin Edgar (1958). Le cinéma ou l'homme imaginaire: Essai d'anthropologie sociologique. Milano: Minuit.

Ministero dei Beni e delle Attività Culturali e del Turismo (2017). Piano strategico di sviluppo del turismo. <https://www.senato.it/ service/PDF/PDFServer/BGT/0 I000578.pdf>.

Nucifora Sebastiano (2006). Contrassegni verticali. Una rilettura del paesaggio costiero siciliano attraverso l'architettura dei fari. Reggio Calabria: liriti editore.

Trimarchi Michele (20 I0). Economia e cultura. Organizzazione e finanziamento delle istituzioni culturali. Reggio Calabria: FrancoAngeli.

Turri Eugenio (200 I). Il paesaggio come teatro. Dal territorio vissuto al territorio rappresentato.Venezia: Marsilio.

Venturi Ferriolo Massimo (2009). Percepire paesaggi. La potenza dello sguardo. Torino: Bollati Boringhieri.

\section{Authors}

Sonia Mollica, Università degli Studi Mediterranea di Reggio Calabria, sonia.mollica@virgilio.it

Andrea Marraffa, Università degli Studi Mediterranea di Reggio Calabria, andreamarraffa89@yahoo.it

Per citare questo capitolo: Mollica Sonia, Marraffa Andra (2020). La riconnessione delle città costiere: La rete dei fari italiani/The reconnection of coastal cities. The network of Italian lighthouses. In Arena A., Arena M., Brandolino R.G., Colistra D., Ginex G., Mediati D., Nucifora S., Raffa P. (a cura di). Connettere. Un disegno per annodare e tessere. Atti del $42^{\circ}$ Convegno Internazionale dei Docenti delle Discipline della Rappresentazionel Connecting. Drawing for weaving relationships. Proceedings of the 42th International Conference of Representation Disciplines Teachers. Milano: FrancoAngeli, pp. 3553-3576. 